\title{
How COVID 19 effect Malaysian paddy industry? Adoption of green fertilizer a potential resolution
}

\author{
Nadia Adnan ${ }^{1}$ (D) Shahrina Md Nordin ${ }^{1}$
}

Received: 10 July 2020 / Accepted: 3 September 2020 / Published online: 30 September 2020

(c) Springer Nature B.V. 2020

\begin{abstract}
The COVID-19 pandemic resulted in more than 4.3 million confirmed cases and more than 2,90,000 deaths worldwide. It has also given rise to fears of an imminent economic crisis and recession. Social distance, self-isolation, and travel restrictions have led to a reduction in the workforce across all economical sectors and have led to a loss of many jobs. Schools have closed down, and the need for commodities and manufactured goods has decreased. On the other hand, the need for medical supplies has increased significantly. The food sector is also facing increased demand as a result of panic buying and storing food products. In response to this global outbreak, we summarize the socioeconomic effects of COVID-19 on the various aspects of the world economy. In Malaysia, the COVID-19 epidemic has checked the resilience of the agriculture sector. Especially the Malaysian paddy industry as country imports $30 \%$ of its overall consumption from different parts of the world. The real price of rice triplicating for the consumers, which was alarming for nations in this pandemic situation. The Government of Malaysia introduced the National Agrofood Policy 2011-2020 (NAP4) in 2010 as a guidance document for the implementation of agricultural sector development programs and projects in Malaysia. The NAP4 's 10-year term is to be finished by the end of 2020. Several sectors demonstrate substantial success after approximately 8 years of introduction, while the other classes often lag behind the goal and progress quite slowly. Agricultural sector performance is affected by many problems and challenges. In acknowledgment of the poor success of this field, the Ministry of Agriculture and Agri-Based Industry has launched new approaches, policies, and programs that can change the agricultural sector more rapidly. The new direction is aimed at ensuring national food security and boosting farm and revenues. The authorized government agency needs to revise the policy formulation where Malaysia needs to set stages to revolutionize and modernize the rice farming to address the problem faced by the paddy sector in this pandemic situation to adopt GF. In this study, the researcher focuses on the improvisation of the policy to increase the paddy production sustainably.
\end{abstract}

Keywords Sustainable agricultural practices · GF · COVID19 - Malaysian paddy farmers

Nadia Adnan

Nadia.adnan233@gmail.com

Shahrina Md Nordin

Shahrina_mnordin@utp.edu.my

1 Universiti Teknologi Petronas, Seri Iskandar, Malaysia 


\section{Introduction}

The COVID-19, first, published in China in December 2019 before spreading across the world more broadly. Labeling as a black swan event and compared to World War Two economic scene (Nicola et al. 2020), the epidemic of COVID-19 (Severe Acute Respiratory Syndrome Coronavirus 2 (SARSCOV-2)) has had a detrimental effect on global health care systems with a cascade impact on any part of human life. Sohrabi et al. (2020) illustrated the severity of the epidemic with the World Health Organisation (WHO) calling the COVID-19 epidemic a global emergency on 30 January 2020. In a response to 'flatten the curve' (Foo et al. 2020), policymakers have imposed border shutdowns, transport bans, and quarantine(Salim et al. 2020). In a developing countries like Malaysia that constitute the world's growing economies, concerns of an impending economic downturn and contraction have sparked off (Salim et al. 2020). The pandemic has a significant impact on Malaysia's agricultural industry, particularly on paddy sector as the country import $40 \%$ of their consumption from different countries. In an effort to explain the tumult Impact on the economy, we summarize the influence of COVID-19 on particular facets of the global economy, concentrating on primary sectors that involve industries engaged in the production of raw materials, secondary sectors engaged in prime mining.

\section{Introduction}

The industry researcher discussed in this research article is none other than agricultural industry. The ultimate challenge for agriculture in the twenty-first century is to produce enough to feed the rapidly growing global population while also reducing the effects of farming on natural resources, increasing ecosystem services simultaneously time tackling climate change and market uncertainties (Reganold and Wachter 2016). A growing global population, coupled with rapid development in the economy and infrastructure in many parts of the world, is placing pressure on natural resources such as agricultural land, water, air, forests, and fossil fuels (Ingrao et al. 2016). Whereas, in the developing country like Malaysia, agriculture plays a vital role in the nation's determination to attain the status of a fully established country by 2020 (Hashim et al. 2017). The Malaysian growth strategy plan is known as Vision 2020 (Lee and Baharuddin 2018). This vision aims to develop the country in all aspects including national unity, social cohesion, economics, social justice, political stability, a system of government, quality of life, social and spiritual values as well a national pride and confidence (Alam et al. 2016).

The government supports the agricultural sector; likewise, for poor people in developed and developing countries, agricultural input plays a vital role in the obtainability of food (access and items), which are two central aspects of food security(Alif et al. 2019). In its development, agriculture remains an essential sector of Malaysia's economy, contributing $12 \%$ to the national GDP and providing employment for $16 \%$ of the whole population and uplifting life in rural communities through extensive activities (Mannan et al. 2017). The involvement of farmers in the agriculture sector in Malaysia in the early years of the country was limited to traditional practices. Farmers often relied on family traditions and focused on planting for their consumption. However, after Malaysia gained independence, the agriculture sector became an essential factor in contributing to the Malaysian economy (Mohamed and Damin 2010). As the years passed, the agriculture sector was transformed 
into an industry that provided employment and food supplies to Malaysians (Fahmi et al. 2013). Agriculture has become more critical year-by-year, and today, agriculture had emerged as an essential sector in the Malaysian economy. The major thrust of the national policy in agriculture is to advance technologically and to increase production in a sustainable manner (Tey 2013).

This study is aimed to investigate how innovations adoption can aid in the promotion of sustainable paddy farming. Ismail et al. (2017) stated that sustainable agriculture refers to the ability of a farm to maintain its production while offering benefits regarding accelerating social growth, conserving the natural environment, and being commercially competitive in a rapidly growing economy. Also, sustainable agriculture encompasses both the aspect of preserving the environment and the aspect of production. The process of bringing an invention to the marketplace, users, and industrial applications is known as innovation. Therefore, innovation, being a vital part of social and economic progress, should be encouraged on a full scale (Tey 2013). The main thrust of national policies aimed at transforming the paddy sector by fast technological progress to boost Malaysian paddy production (Thestar 2019). An eco-innovation that often involves the use of fertilizers to stimulate indigenous microorganisms with the capacity to detoxify certain environmental pollutants is also being threatened using chemical fertilizers, particularly in highly sensitive environments (Hashim et al. 2017). The term eco-innovation is used to describe processes and products that contribute to the development of sustainability (Borges et al. 2015). Developers use eco-innovations to elicit ecological improvements, either indirectly or directly, through the commercial application of knowledge. Many times, they use them to characterize a range of related ideas, from innovative paths leading 0to sustainability, which are socially acceptable, to technological advances, which are environmentally friendly (Borges et al. 2015).

In the agricultural sector, green fertilizer (GF) refers to new fertilizer input (Hazra 2016). The importance of GF to agriculture has grown since 1960, as farmers at that time were unaware of farm production enhancement using GF (Pingali 2012). Currently, the paddy sector is lagging in comparison with the other industries regarding the adoption rate of new, more sustainable innovations such as the adoption of GF (Mannan et al. 2017). It is significant because most of the outdated or conventional agricultural practices have barely achieved the desired efficiency regarding maximized yields or minimal production costs (Bowman and Zilberman 2013). Under such systems, fertilizer and pesticides are applied as inputs for increased production level by benefitting from recent innovative sustainable agriculture technology (Tey 2013). Technologies and innovations, which affect the economic and social viability of farming, are important issues for policymakers. During this pandemic situation, it has been shown that there is need to adopt new technology fertilizer in order to increase the production and become self-sufficient as a nation on paddy.

\section{Literature review}

\subsection{Background of agricultural industry}

As sustainability has several meanings, however, the term sustainable agriculture relates to the capability that a farm has to produce food for an indefinite period, without resulting in irreversible damage to the health of the ecosystem (Abdollahzadeh et al. 2015). Two main issues facing agriculture as cost (the long-term ability that farmers have to manage 
resources such as labor and inputs) and biophysical (the long-term effects on soil properties by the use of various practices and the processes needed for crops to be productive) (Mohamed and Damin 2010). There were several agricultural commodities such as paddy, rubber, coconut, and palm oil that are need to grow through sustainable means (Tey et al. 2017). The government focuses more on paddy farming as it is a staple food for Malaysian (Hassan et al. 2019). Malaysia consumes $110 \mathrm{~kg} / \mathrm{yr}$ of paddy per capita to meet individual rice demand. However, rice consumption is not up to the mark (Thestar 2019). Although the average paddy farmers use about $5.56 \mathrm{~kg} / \mathrm{ha}$ (667 MJ / ha) of various chemical fertilizer pesticides which include insecticides, herbicides, and fungicides (Muazu et al. 2015), it is, therefore, evident that the costs of inputs are high in Malaysia. Most of the chemical pesticides and fertilizers used by farmers in Malaysia are imported; however, there is a government subsidy to supports packages on paddy cultivation (Muazu et al. 2015). Chemical synthesized fertilizers are readily available and known to increase plant yields because, most of the time, fertilizers supply nutrients above plants requirement (Hashim et al. 2017). Its non-biodegradable nature makes them accumulate in the environment, leading to soil damage, contamination of groundwater, change in microbial community structure that provides resistance to pest, contamination of water bodies through runoffs and the resulting eutrophication problems. The continuous use of chemical fertilizers to enhance paddy yield poses a potential risk to soil quality, food security, and agricultural sustainability (Ning et al. 2017).

\subsection{Adoption hindrance}

However, we found that there have been several challenges acknowledged to inhibit the adoption of innovation and technological advancement in the paddy farming sector in Malaysia even in this pandemic situation faced by the country. Local studies produced by Shaffril et al. (2018) have pointed out such challenges including a lack of education, negative perceptions, lack of capital, small land areas, ineffective infrastructure, and workers with limited ability. Without proper knowledge of new technology, farmers tend to perceive innovation as unnecessary and unwarranted. It is not helped by the fact that these farmers receive massive subsidies from the government for their farming activities from direct cash aid to assist in farming input (Lee and Baharuddin 2018). In this case, over-reliance on fertilizer subsidies and other government assistance affects the initiative of farmers to seek solutions to improve their paddy productivity level (Lee and Baharuddin 2018). Another main factor influencing the adoption rate is age. Old farmers tend to rely on traditional practices and might be less willing to take the risk associated with adopting a new method. In fact, according to Ali et al. (2018) mentioned that old farmers are more likely to face difficulties in adopting new technologies, and, as a result, the adoption of innovations usually is discontinued and harder to be sustained. In the case of Malaysia, many paddy farmers are old, with Alam et al. (2010) showing that the average age of the group is more than 46 years.

Putting the challenges above into perspective, inspecting agricultural technology adoption decisions has gained interest among scholars over the past decades (Haris et al. 2018). Numerous researches on adoption decisions in the expanding industry of the agriculture sector have been performed throughout the world (Abdulkarim et al. 2017). For example, for developed nations, several technologies have been examined to increase the yields, at the same time, various factors have been identified to decide to adopt the innovations, Whereby, in the context of emerging nations, the decision making geared toward 
the adoption of innovations in agriculture is not perceived to be effective. The innovation researcher discussed is to maximize the rate of green fertilizer application; there is a great need to understand farmers' adoption decision behaviors (Adnan et al. 2017).

Moreover, all this research has occurred in separate fields such as sociology, economy, policy, environmental concern, agriculture extension, psychology, communicational aspects, and the marketing perspective (Adnan et al 2019; Jones et al. 2015; Prokopy et al. 2008). In most of the research, the farmer's decision-making stage depicts the desire to embrace innovation (Zeweld et al. 2017). Furthermore, several authors such as Mannan et al. (2017), and Morais et al. (2018) have recommended the necessity of a formal combination of communication channels, socio-psychological, and innovation attributes constructs in related models. This concern should be resolved to achieve better knowledge from a farmer's decision perspective concerning the adoption of an innovation (Jara-Rojas et al. 2016). The studies from researchers suggest that the adoption of innovation-decision relies on a broad range of factors like communication channels, socio-psychological, policy factors, environmental factors, socioeconomic factors, and innovation attributes.

In Malaysia, a major initiative was taken to promote soft innovation in agro-based, environmentally friendly technologies among farmers such as green fertilizer (GF) (Hashim et al. 2017; Thestar 2019). Also, Adnan et al. (2017) GF implementation aim is to link agriculture with environmentally friendly innovations, which contributes to increased production and the development of sustainable agriculture (Ghadiyali Tejaskumar and Kayasth Manish 2012). General agreement exists that the increased use of GF and other productivity-boosting inputs produce benefits regarding rural productivity growth and poverty elimination. Hence, the increased use of GF is the target of economists, agriculture scientists, and government institutions to help achieve the benefits. These benefits have begun to be reaped in many developed countries that have to invest in GF. The utilization rate remains very low in developing countries, including Malaysia (Tey et al. 2017).

The application of GF is required for different agricultural commodities like palm oil, cocoa, rubber, and paddy (Mannan et al. 2017). Government institutions and policymakers, in general, agree on the urgency to further increase the use of GF in Malaysia (Adnan et al. 2017). By giving the current growing economic condition of the country and the further need to boost the country's food self-sufficiency, this researcher agrees with the consensus about the need for GF adoption to be more widely used within the paddy farming sector (Rabu and Shah 2013; Rahim et al. 2012). In the paradigm of this research study, researchers have emphasized the paddy industry because it is one of the most significant agricultural commodities in the country (Rahim et al. 2012). Indeed, paddy crops have been growing in both east and peninsular Malaysia (Mannan et al. 2017).

The role of government in sustaining the paddy farming industry must not be overlooked (Thestar 2019). Sustainable paddy farming is especially important because the Malaysian government is aware of the importance of the industry in strengthening national food security and self-sufficiency (Thestar 2019). The responsibility is put under the works of the Ministry of Agriculture and Agro-based Industry (MOA), through its agency, the Integrated Agricultural Development Authority (IADA). The agency is responsible for ensuring that rice production meets about $72 \%$ of the demand in the country.

Therefore, the concern is not only based on specific policy on food security but through self-sufficiency, which focuses on local production to meet the rice consumption rather than import in Malaysia (Alam et al. 2017). The government has set the range of 10-35\%-imported rice to the over demand for rice in the country (Alam et al. 2016). In the 10th Malaysian Plan, a 5-year economic plan from 2011 to 2015, the government set the local production rice at $70 \%$ of the self-sufficiency rate (Alam et al. 2016). The 
paddy farming industry also receives a substantial subsidy from the government. On average, the Malaysian government spends about 300 million USD annually for fertilizer alone (Adnan et al. 2019). It does not include other forms of assistance, including grants, other agriculture inputs, and cash assistance to farmers. It is not difficult to comprehend why policymakers have put much focus on the paddy industry as it provides staple food for the country apart from palm oil (Fahmi et al. 2013). It is essential, particularly by given that the annual output of rice needed is approximately 11.0 million tonnes, whereas the real production is only 2.51 million tons. Thus, production does not meet consumption requirements (FAOSTAT 2015; Thestar 2019). To increase paddy production through sustainable agricultural development is a foremost concern of the government policy, which can be met with the adoption of GF. Whereas, control released fertilizer achieves two main objectives, such as increasing the production level but also it produces a sustainable environment.

Despite previous studies on this issue, GF adoption research has been restricted to only a discussion of the intention of paddy farmers toward the adoption decision from the Malaysian perspective. Other studies have established that most farmers are unable to comprehend "green" terminology in the context of Malaysia as well as its significance, which could assist the farming community in improving production by maintaining sustainable environmental practices.

To allow farmers to comprehend the value of the adoption of innovations, creating awareness about the innovation and proper communication channels (Hezri and Ghazali 2011; Muazu et al. 2015) is necessary. Past research has examined the behavior and decision making from economic and non-economic perspectives individually. For example, the wholly economic studies of Austin et al. (1998) and Davies and Simonovic (2011) argued that adoption decisions among the farming community heavily rely on normative theory. The normative theory has presumed that decisions can only be validated when farmers get the most profits.

TPB has been widely used in studies of the behavior of individuals and its links to attitudes, beliefs, and behavioral intentions. The argument in TPB is that behavior is the product of an individual's intentions. Intentions, in turn, are derived from three aspects of psychological constructs; those are attitude, perceived behavioral control, and subjective norm. In brief, the attitude in this study refers to how farmers give out an evaluation of the adoption of GF, be it positive or negative (Wauters et al. 2014). Next, perceived behavioral control focuses on a farmer's perceived capability and means to adopt GF innovations. Lastly, the subjective norm is defined as "the perceived social pressure to perform or not to perform the behavior (Ajzen 1991) (adoption of GF) in question.” Social pressure comes from people within the vicinity of each farmer, e.g., family members, relatives, and friends. To add to this, the researcher also proposes the integration of the group norm into the study. What sets a group norm apart from s subjective norm is that the social pressure comes from a specific group of people, in this case, a pool of paddy farmers, in the same community.

Putting all these into consideration, an analysis of these four aspects (attitude, perceived behavioral control, subjective norm, and group norm) allows this researcher to assess their influence as determinants in affecting the adoption decision of paddy farmers in Malaysia. The researcher is also interested in observing how the awareness of the paddy farmers to the adoption of GF enhances the understanding of the adoption decision of the Malaysian paddy farmers (Mannan et al. 2017). Farmers' knowledge and awareness of the implementation of the GF attempt to consider how the decision to implement the GF is influenced by new facts and expertise on the GF. In other words, the researcher is keen to gauge to what extent awareness of environmental factors influences the decisions of paddy farmers 
to adopt GF (Mannan et al. 2017), ensuring that pricing and cost are being examined as essential factors for adopting GF. A few other studies have found that if the costs are low, then the adoption of any innovation is higher (Hassan et al. 2019).

To enrich the understanding of the behavior of the target group in the study that is paddy farmers in Malaysia, the researcher also relies on another theory, which is Rogers' (1983) Diffusion of Innovations (DOI) theory (Adnan et al. 2019). The theory provides a useful tool for describing the pattern of adoption for explaining the mechanism of adoption for innovation, more importantly, in predicting the degree of success of the adoption. Rogers (2010), in his argument, states that DOI is a process by which an innovation is propagated throughout a community via individual channels over a period (Tey 2013). Relative advantage is the degree to which an innovation like GF is perceived as a better alternative than the current option; in this case, conventional agriculture practices (Smith et al. 2018). Comparative advantage is positively related to the adoption rate. In other words, the rate of adoption of GF will be high if the target groups of adopters perceive that it has unique benefits and is superior to traditional farming and other practices in their surroundings (Jerneck and Olsson 2014). Complexity refers to measure an innovation (in this case, GF) is perceived as relatively difficult to be understood and implemented. The complexity of an innovation (GF) as perceived by the potential adopters is inversely related to its adoption rate. Trialability refers to measure an innovation (GF) which may be tested on a limited basis such as Franzel et al. (2014) stated that in the case of trialability, the adoption rate was higher if the trialability approach can be implemented correctly in the way to adopt innovation. Observability is a measure to which potential adopters can perceive the results of innovation (Rogers 2010). Greater observability was more likely to influence a higher adoption rate (Mannan et al. 2017). For example, if GF adoption results in visibly increased yields (or decreases costs visibly, e.g., by reducing labor), then there is a better chance that GF will be adopted. Lastly, compatibility of an innovation is perceived as the degree of consistency of the innovation with the existing values, preceding experiences, and the current needs of potential adopters (Rogers 2010). The chances of adoption are higher if innovation is perceived to be of higher compatibility.

The significant aspect that also comes from DOI is that Communication channels are the avenues by which a message is transmitted from a source to a receiver (Mannan et al. 2017). Two types of communication are usually observed, such as interpersonal or mass media in nature; another one either originates from a specific source or a pool of sources (Adnan et al. 2017). Franzel et al. (2014) stated that the source of communication is a more diverse way, which leads to a higher adoption rate. One example would be the use of mass media and other diversity to promote information on GF through social groups and denominations (Fairuz et al. 2017). This process would have a better chance of influencing the adoption of GF by Malaysian paddy farmers than would depending exclusively on interpersonal communication between the farmers.

Another theory included in the research framework is the Technology Acceptance Model (TAM) developed by Davis (1985). This model predicts the adoption acceptance of consumers toward a technology based on two variables: perceived usefulness and perceived ease of use. These two shapes the attitudes of potential adopters whether to adopt the technology or not, which, in turn, influence the behavioral intention to use a technology (Davis 1985). Perceived usefulness is the degree to which a person believes that using technology will improve performance among farmers (Schaak and Mußhoff 2018). Whereas, perceived ease of use, meanwhile, refers to the degree to which a farmer believes that the use of innovation will require little effort. Several factorial studies have demonstrated the effect such as principles which are used to elucidate the innovation to understand farmers 
behavioral intention to use the adoption such as perceived usefulness and perceived ease of use as TAM's aim is to structure the current behavioral structure (Abdollahzadeh et al. 2015). In the line of this research study, the components of TAM are included in the framework as the awareness of the paddy farmers regarding GF regarding its usefulness and ease of use. Researchers further use one of the primary constructs of TAM that is (Siddique et al. 2013). Perceived cost is defined as the degree to which a prospective user thinks that GFs are expensive.

Nevertheless, no research so far discusses the integrations of TPB, TAM, and DOI, the socio-psychological, socioeconomic, innovation attributes, environmental factors communication channel, and policy factor in explaining the paddy farmer's adoption decision for GF. Thus, this research intends to fill this gap of minimal focus on literature and assess its significance in improving the adoption of GF among Malaysian paddy farmers. Given its potential in helping farmers to improve yields as well as providing them with better knowledge of sustainable environmental practices. Therefore, this research is adding to previous frameworks to create a better understanding and adding to the research domain. On a larger scale, this study will help policymakers and other key personnel in developing strategies to widen the use of GF among paddy farmers by taking into consideration the adoption decision of the group of paddy farmers. It is indeed essential for the relevant agencies and personnel to be informed to avoid misguided policy implementation. Hence, it is expected that by choosing the adoption decision of paddy farmers about GF as a research context, it is essential to keep all the crucial aspect decisions and the reasons why/how these decisions were made. Therefore, it also justifies any decision taken. It also hindsight will aid improved decision-making in the future.

\section{Problem faced by the rice industry}

\subsection{The world rice situation}

The global food crisis is on the rise, showing the plight of 113 million people facing severe hunger for urgent food (FAO 2019). The worldwide population's exponential growth reaches 7.5 billion, with Asia's primary (FAO 2019). For most Asian countries, rice is the staple food; people of this region consume over $80 \%$ of the world's rice (Sarena Che Omar and Tumin 2019). Throughout the latest food crisis in 2007 and 2008, the food price index grew by 54 percent from January 2007 to June 2008, with the real price of rice triplicating for the consumers, which was alarming for nations across Asia, both Thailand and India took action to limit their exports of rice after India's drought (Freiner 2019). Global food demand, particularly in Asia, is expected to rise by $60 \%$ from 4.5 billion tones in 2000 to 6.9 billion tons in 2050 due to its strategic nature (Sarena Che Omar and Tumin 2019).

\subsection{Malaysia's rice situation}

In developing, nations such as Malaysia have felt the heat of this rice demand (Barik et al. 2019; FAO 2019; Jamal et al. 2014). The agriculture minister specified that Malaysia imported 740,000 tons of rice last year, which cost them RM1.18Billion (Thestar 2019). As a result, the government beefed-up its efforts by creating the National Agricultural Policy (Dardak 2015; Osman and Shahiri 2017). Minister of Agriculture Datu Salahuddin stated that the government set a target to increase the production of local rice by up 
to $75 \%$ in the next three or 4 years (Thestar 2019). Furthermore, he stated that in order to increase production, the government looks at the new technology, such as using a better variety of fertilizers (Thestar 2019). As paddy has always given special treatment based on its strategic importance as it is a staple food for the nation, however, government intervention policy such as fertilizer subsidy on the Malaysian paddy farmers and the government developed to aid the Malaysian rice industry (Rahim et al. 2012). The government gives subsidies to the paddy farmers as Malaysia is among high-cost producers, where the average cost of production in the granary is nearly RM3024 per hectare (Harun 2017). Due to that fertilizer subsidy scheme, farmers receive about $100 \mathrm{~kg} / \mathrm{ha}$ or 240 compound fertilizer $40 \mathrm{~kg} / \mathrm{ha}$ or $80 \mathrm{~kg} / \mathrm{ha}$ urea fertilizer per hectare for paddy cultivated (Harun 2017). However, paddy production is still not enough to meet consumption needs (Thestar, 2019).

\subsection{Malaysia's food security: a need for green fertilizer innovation diffusion}

According to Hashim et al. 2017, the biggest obstacle faced by government agencies toward implementing GF (CRFs) among farmers is the insufficient information due to communication barriers and farmers being unaware about the "green thing" and the environmental crisis. Farmer's unawareness of the environmental problems and possibilities of green fertilizer implementation prevents them from adopting GF (Hashim et al. 2017). Although the rigorous efforts of the government have considered all the possibilities, still farmers remain unfamiliar with the idea of sustainable practices with GF (Naher et al. 2019). To date, the literature highlighted that adoption of GF is the main issues although government makes various effort to make farmers aware about GF, but the adoption rate is still low (AlSamarrai et al. 2018).

Adnan et al. (2019) mentioned that concerning the National Green Technology Policy of Malaysia, enough information and farmers' awareness are two of the main factors that would help them to make adoption decisions for GF. This concern is particularly substantial as such adoption requires changing the mindset of farmers through various approaches, including their effective agricultural communication, knowledge education, and information dissemination to increase farmer awareness to make an adoption decision relative to GF (Mannan et al. 2017). Most researchers like Adnan et al (2017) and Shamshiri et al. (2019) have stated that farmer's awareness of GF adoption and the depletion of resources can help to increase paddy production.

To create awareness, effective communication can build trust among paddy farmers toward the adoption of GF, which consequently strengthened the relationship between the policymakers and farmers and help to reduce conflicts (Poppenborg and Koellner 2013). One principal value of the effective communication process is information, and part of the most critical function of communication is to transfer and gain valuable information about the adoption of GF (Mannan et al. 2017). The application of GF in agricultural practices would enable Malaysia to achieve agricultural sustainability and also increase the level of production (Adnan et al. 2019). Adoption is the early stage of technology utilization, as diffusion of technology subsequently propagates the technology among the members of a social system via several communication channels (Rogers 2010). Furthermore, Rogers (2010) proposed a framework to investigate the unacceptable level of innovation diffusion and what caused the level to shift up or down. In a more recent study, Ingram (2018) pointed out the importance of scaling up the diffusion process in a more extensive general adoption process, noting that "Practitioners, policymakers, researchers, and funding 
agencies would agree that there are insufficient knowledge and experience to address most problems lack of communication."

Morais et al. (2018) specified that the number of farmers deciding which agricultural innovations are implemented for their farms is restricted. Thus, the adoption of innovative GFs depends upon the mindset of farmers because they grow the crops to feed their families or to sell and earn a living in a market economy (Mannan et al. 2017). Studies about the adoption of GF in the agricultural sector are not new, and many studies have attempted to develop knowledge on this topic (Adnan et al. 2017). Several researchers such as (Borges et al. 2015) have argued that the level of innovation adoption decision among farmers is still low especially concerning modern agriculture practices because farmers' decisions to adopt GF depend on complex factors. In general, farmers adopt an innovation if they expect that it will help them to achieve their objectives (Greiner and Gregg 2011). An adoption decision for innovation takes place among farmers when they know an innovation well or that innovation conveyed to them appropriately Adnan et al. 2019. Adoption also depends on the socioeconomic, biophysical, cultural, and local settings that need to be taken account when trying to determine any limitations (Midingoyi et al. 2019). In most of the studies, researchers have recognized that the prospective implementation of agricultural technologies in Malaysia is area-specific. The researchers have put a great deal of emphasis on socioeconomic aspects and ecological conditions the newly introduced innovations are the most suitable in smallholder farming in Malaysia (Adnan et al. 2019) as well as their potential for scaling up regionally. Tey et al. (2017) study considered the best possible options to determine the necessary constraints that prevent innovation adoption. Furthermore, their research supported the idea that it is crucial to look at the adoption of agricultural innovation as a process marked by interaction instead of in a static sense (i.e., as a situation determined by one or more influencing factors) based on SAP (Tey et al. (2017)). Although Alam et al. (2019) stressed that incentives and economic compensation could work as critical variables leading to the adoption of technologies among farmers. However, this alone is not sufficient to achieve any findings concerning the farmers' decision-making process. Sometimes, the decision for adoption is based on subjective perceptions or expectations rather than on an objective truth (Tey 2013). According to Adnan et al. (2019), these perceptions depend on three broad sets of issues: (1) the process of learning and experience, (2) an innovation should be well diffused among farmers, and (3) the social environment of farmers. Furthermore, Gaudino et al. (2014) stated that agro-environmental policy plays an essential role in the adoption of innovation.

The implementation of environmentally friendly practices is weak in the agricultural sector in Malaysia (Thestar 2019). The Malaysian government is willing to invest in environmental management systems and eco-practices, promote green products, or invest in the implementation of environmentally friendly practices (Thestar 2019). Additionally, various barriers exist that prevent a change toward green practices. Such barriers include weakly enforced environmental laws and regulations, scarce and intermittent green supply chain, non-existent trade pressure, and low consumer and community demand for GF to implement green practices (Adnan et al. 2017). The unsettling primary concern about the adoption of GF is the costs that are associated with this innovation (Hashim et al. 2017; Mannan et al. 2017).

Extending on this line of study, Aker (2011) identified four variables that can affect the adoption decision: (1) farmer behavior, (2) social milieu, (3) proper communication, and (4) innovation characteristics. As per Eder et al. (2015), communication is a crucial factor in getting farmers to adopt an innovation. Hence, enhancing effectiveness in communication and reducing the barriers that are associated with the communication to increase 
paddy production is vital (Shaffril et al. 2010). The research problem is the paucity of a holistic model for developing adoption behavior, especially in Malaysian paddy farmers. Previous models are based mainly on the conceptual aspect of agricultural innovation (Tey 2013; Adnan et al 2019) or other researcher focuses only on innovation attributes is the factors that affect the adoption which is an unreliable evidence (Mannan et al. 2017). In general, the current models describe farmers' acceptance of innovation based on the sociopsychological aspect (Borges et al. 2015; Conway and Barbier 2013; Prokopy et al. 2008; Shaffril et al. 2018). However, no such model exists which explain the factors that influence the adoption of innovation among paddy farmer toward the awareness of farmers knowing the about the GF. This research, therefore, permits an academic investigation intends to develop a model that indicates the factors influencing the adoption of GF. From the marketing point of view, the present research identified three possible constructs namely sociopsychological, innovation attributes, communication channels, socioeconomic, policy factors, and environmental factors (Tey et al. 2017). Perhaps there is no research-based on theoretical grounding in Malaysia, which accommodates the behavior of farmers along with all the related issues. Thus, this proposed work will help to understand the decisions of a farmer concerning the adoption decision of GF.

\section{Adoption of agro technology}

\subsection{The concept of agricultural innovations}

Considering the history of agriculture dating back to the Ancient Period, it is not surprising that agricultural communities are familiar with technological improvements and innovation. The community also tends to be quick at adopting innovations, whether they are chemical (pesticides and fertilizers), biological innovations (new seed variety), animalrearing innovations (feeding and breeding), or mechanical advancements (machinery). The adoption of these innovations usually stems out from the urge to increase production and, in turn, their income (Adnan et al. 2019). In simple words, technological advancements offered multiple solutions to problems faced by the farmers, such as inadequate income, unproductive crop yields, and operational incompetence. Mannan et al. (2017) pointed out that innovation gives a window of opportunity by introducing a new way of doing old things. Adnan et al (2017) stated that innovation is an intrinsic part of the people and highly regarded in the development of society. All these views form a suggestion that the potential to innovate is inherently natural within us all, so what makes an individual not to adopt innovations? The researchers might have a look at the wrong issue without realizing the real issue has to do with the technologists' development method to innovations. There are two types of technology soft and hard in the agriculture sector (Wheeler et al. 2017). In line with this research, the researcher discusses soft technology because it can change a situation or to the evolving needs (Zepeda et al. 2014).

\subsection{Major paradigms adoption of agricultural innovations}

The major paradigm for the adoption of agricultural innovation is listed below. 


\subsubsection{Agriculture productivity: diffusion of innovations}

While much of the research in agriculture is focused on the development of innovation, technical changes, and the economic perspectives, there is little discussion considering the efficiency of production among farmers (Thompson, Reimer et al. 2012). There is research that stressed on the agricultural productivity toward the adoption of new fertilizer innovation. Adnan et al. (2017) asserted that productivity would remain low if the capacity of farmers and other players in the agricultural value chain keeps on stagnant; in fact, it prevents them from being innovative. Based on Mannan et al. (2017) research, there are four steps of farmers' capacity building, to enhance their agricultural productivity: (1) building the capacity through $R \& D$ environmental factor (2) transferring knowledge through the extensions-based socio-psychological aspect (3) building capacity through non-formal education method such as communication, and (4) building capacity to create awareness about the innovation. Therefore, the involvement of farmers in this process is the key to success and requires full capacity so that they can seek knowledge and information through new findings and process it into innovations. There is a dire need to support farmers to increase rice productivity rather than acreage cultivated so that the improvement in rice productivity potential will be more significant and meet the requirement of the shortfall in rice production (Bates and Block 2013).

\subsubsection{Malaysian agriculture: a marketing perspective}

This study links the Malaysian agriculture market for agri-innovation to connect new fertilizer innovation with the problems of research and innovation. Hashim et al. (2017) specified that it is regarded as how agricultural innovation diffusion is crucial, over the importance of new fertilizer innovation in a marketing system. Furthermore, Fatah et al. (2017) stated with the increase in agricultural innovation, the profitability of farmers in a more sustainable manner through more efficient use of funds. This is of the principal significance of a new fertilizer innovation, which is based on a more circular economy that elevates the progression of the market. Awareness of these variables could enable the creation of strategies, policies, and plans to improve the uptake and support of agricultural technologies in the manufacturing and marketing of innovation, thus contributing to the food safety and income of farmers through increased productivity and crop marketing (Adnan et al. 2019).

\subsubsection{Agriculture sector in Malaysia: productivity}

Agriculture has always been an integral economic activity in Malaysia (Hosseini and Wahid 2013), despite the Malaysian governments emphasize on becoming an advanced industrial country. It is evident from the Vision 2020 plan proposed by the then Prime Minister, Dr. Mahathir Mohamad, who viewed the agriculture industry as a "sunset industry" (Bakar 2009). Nonetheless, the Malaysian government has expended significant efforts to make it a growing industry. As one of the most important contributors to the national economy, agriculture has a role and a challenge in delivering food security to the population, as well as generating wealth for rural communities throughout the country (Shaffril et al. 2010). Currently, a total land area of 329,733 square $\mathrm{km}$ has been devoted to agricultural activity, though some areas have a high acid level in the soil and are thus deemed as infertile (Shaffril et al. 2010). Agricultural production has contributed about $11.6 \%$ of the total 
Malaysian GDP, despite being overshadowed by the rapid industrialization of the country, starting in the mid-70 (Haris et al. 2013). Despite the expansive effort by the government to industrialize the nation, the agricultural sector remains significant, although it has become of less importance.

\subsubsection{Malaysian paddy farming: a global scenario}

In 2008, the world's total production of rice stood at 685.0 million tons, increasing at a rate of 9.5 million tons per year (Sarena Che Omar and Tumin 2019). Whereas, Table 1 illustrates countries in the league of the top ten largest producers of rice are as follows. While Thailand remains one of the primary rice exporters, the nation has seen manufacturing decrease and complete rice harvested region over the past 5 years (Sarena Che Omar and Tumin 2019). Malaysia has shown an almost steady trend in rice manufacturing, harvested region, and even rice SSL compared to the other SEA nations. Still, it has the second-largest average annual rice yield development at 1.6\% after Vietnam at $1.8 \%$ between 2000 and 2016. Vietnam was an unusual situation, showing the most significant rise in rice manufacturing and SSL behind a comparatively slower rise in paddy soil. It has shown a gradual rise in the manufacturing and harvested region in the Philippines since the $1990 \mathrm{~s}$, with SSL floating below 100\% (Sarena Che Omar and Tumin 2019).

Even though the land area for rice has remained rather constant, Malaysia's rice productivity is slow, where the country can produce nearly $72 \%$ of its overall consumption (Thestar 2019). Thus, the government's agricultural industry stated dire need that paddy needs to increase each year; however, the government makes numerous efforts to increase paddy production (FAO 2015).

The importance of the agricultural industry was elevated through high commitments from various component agencies related to the agriculture sector. During the Eighth Malaysian Plan period (2001-2005), the focus was given to enhancing the development of agricultural land, particularly concerning increased agro-community productivity. The in-situ land development approach continued to be adopted as a strategy to utilize the land resources of smallholders even better and to overcome the limitations of suitable land (FAO 2015). The improvement of production and value-added products for exports inspired farmers to shift into large scale and commercial farming, and the broadening of adoption of the group farming system was an indicator of the high performance of the agriculture sector during this time. During the duration of the plan, paddy production was increased due to the fully mechanized farming operations, and as a result, the income of farmers was further increased (Mirimo and Shamsudin 2018).

Thus, Malaysia can feed its population if the supply is maintained up to $10 \mathrm{mt} / \mathrm{ha}$ per season for each granary areas. There is a dire need to achieve self-sufficiency level (SSL) at 80 percent as recommended in FAO report (or even 70 percent as under the Tenth Malaysian Plan (2011-2015) target) to maintain the stockpile for a more extended period which may result on the sustainable national consumption for more than 45 days. Support from various agencies, government, extension agents, and policymakers may help farmers to improve their yield production up to $10 \mathrm{mt} / \mathrm{ha}$. Moreover, the plan period (2016-2020) emphasized food security through sustainable means that would strategically address the availability and accessibility of food, particularly in rice production and consumption of the nation.

According to FAOSTAT (2019), the annual production of rice was around 2.51 million metric tons. However, rice production, which is estimated at 3.66 metric tons per hectare 


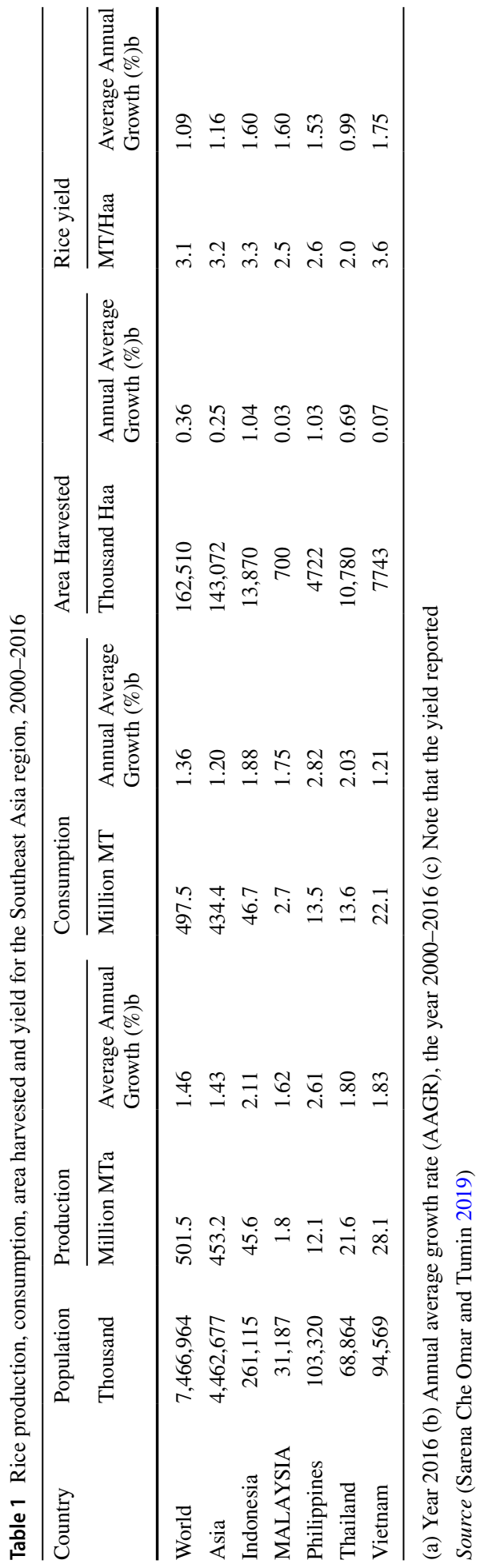


from the total land area on 672,000 hectares (1.66 million acres) on which rice is grown, does not meet actual consumption needs. To fix the issue of low production, farmers need to adopt new fertilizer innovation.

\subsubsection{Malaysian paddy farming: innovation scenario}

Advancements in agricultural technology have changed the dynamics of how human beings perform their work today in virtually all sectors of productivity (Adnan et al. 2019). Technology has influenced the labor associated with agricultural farming and the performance of agriculture globally, and Paddy production has also experienced a change regarding how farmland activities are undertaken (Adnan et al. 2019). Whereas, Alam et al. (2016) have argued that technological change has been a significant factor over the last 100 years, and these changes have reduced the amount of labor needed and increases outputs. National paddy productivity can develop from various factors interaction. Some of the most critical factors were included in technological change, organizational change, industry restructuring, and resource reallocation (Rabu and Shah 2013). Toward a certain extent, other factors such as research and development $(\mathrm{R} \& \mathrm{D})$ and innovative effort, the development of human capital through education, and incentives from the substantial stakeholders will also promote the ability to improve productivity.

McDonald et al. (2016) noted that the adoption of technological innovations in agriculture had attracted considerable attention among development economists because the majority of the population of less-developed countries derived their livelihoods from agricultural production. Pagani et al. (2017) specified that because of new fertilizer innovation technology, which offered the opportunity to increase production and income substantially measured as a partial success, which observed by rates of adoption. The adoption of new fertilizer innovation directly influences agricultural productivity by affecting the way, and it improves human capital affect acquisition, assimilation, and implementation of information and technology.

In the Malaysian context, the potential of paddy toward $10 \mathrm{mt} / \mathrm{ha}$ can be achieved through the implementation of higher soft technology application such as improved crop and soil management, new fertilizer technology, control of pest and diseases with the best practices as well as the performance of high seeds variety (Hashim et al 2017). Although many efforts had been undertaken, the real issue is on the farm itself, and farmers are the contributing factor that should not be overlooked. Instead, the problem was not on the lack of new fertilizer technology, but instead equipped farmers with knowledge and support network to modernize the way they do the business (Hashim et al 2017). To achieve a productive farmer, first, there is a need to capture their mindset to focus on the right decisionmaking, because once they make the right decision, it was manifested through realistic an accurate prediction of behavior (Yusof et al. 2019).

Hence, adoption decision of innovation among farmers is so crucial because it helps individuals to identify and choose alternatives based on the principles and preferences of the decision-maker. The right decision-making is very crucial to every single farmer to achieve higher yields and yet enables farmers to become successful and contribute to national consumption (Shaffril et al. 2018). However, there may not always be a 'correct' decision among the available choices that had not been considered, or the right information may not have been available at the time. It is essential to keep a record of all critical decisions and the reasons why/how these decisions were made, so that improvements can be made in the future. However, Adnan et al. (2019) justify any decision, as pointed 
out in a study of Nigerian farmers, was that communication about agricultural innovations was flawed and that more research should consider the channels of communication through which information about innovations is disseminated. According to Adnan et al (2017), one channel of communication is the extension agent, who plays a crucial role in demonstrating the efficacy of innovation such as a new type of seed, pesticide or fertilizer in local conditions. An extension agent finds all required information, technical skills, and knowledge related to innovation, so he can teach and transfer those skills to the farmers effectively. Thus, proper communication can be useful in strengthening the technical skills required for farmers to adopt an innovation (Shaffril et al. 2010). Some studies suggested farmer's adoption influence by their socio-psychological aspect (Borges et al. 2015). Furthermore, Mohamed and Damin (2010) noted that effective innovation diffusion and policy means that coalitions of actors must be formed to create effective partnerships to meet the challenges of food security. It is also noted that multiple diffusion models must be adapted to account for differences among farmers and local conditions.

\subsubsection{Malaysian paddy farming: a new fertilizer technology}

In Malaysia, all kinds of farming systems use mineral fertilizers that make up more than $90 \%$ of the fertilizers. The fertilizers that farmers most commonly use are ammonium sulfate, urea, calcium ammonium nitrate, superphosphates, phosphate rock, ammonium phosphate, potassium sulfate, potassium chloride, and NP, PK, and NPK compound fertilizers (Adnan et al. 2017). An increase has occurred in fertilizer use because of crop production expanding rapidly, most notably with plantation crops (oil palm, rubber, paddy, and cocoa (Adnan et al. 2019). Locally, manufacturers produce large amounts of urea, organic, and ammonium-based fertilizers, but Malaysian farmers use urea that is not locally produced for their agriculture needs. The reason for this is that, when manufacturers make pilled urea in Malaysia, they mostly export it because it sells for a high price on the international market (Mannan et al. 2017). The leading company producing fertilizer has two subsidiaries that are involved in the manufacturing of urea. Still, most of the fertilizer that farmers use in Malaysia come from abroad because of the cost (Rupani et al. 2017).

A farmer's adoption of fertilizer highly depends on their availability and their resources to purchase fertilizers, and the effect of fertilizer on production is contingent on a farmer's application (Serra and Lansink 2014). Therefore, Adnan et al. (2020) argued, access to suitable information about the suitability of a fertilized by farmers may have noteworthy impacts on technology adoption and agricultural productivity. In order to overcome the issue of low production, the government provides all paddy farmers with subsidized fertilizer, a program that began in 1970 (Adnan et al. 2019). Nonetheless, Malaysian rice production has remained unable to achieve self-sufficiency in food production for its population. Furthermore, the paddy industry has not generated enough income compared to other commodities, which is mentioned in Table 2.

Currently, however, the country only manages to produce about $60-65 \%$ of rice necessary to achieve self-sufficiency. The rest is met through import activity, mostly from Thailand (Haris et al. 2013).

Malaysia's Gross Domestic Product (GDP) was RM1196.4b in 2016, with only RM106.5b (8.9\%) contributed by the agriculture, forestry, and fisheries industries. Palm oil was the most significant contributor in agriculture at RM41.9b (40.2\%), while paddy only contributed RM2.4b (2.3\%). Palm oil has always been a significant contributor to domestic GDP, and this can be seen over time as the oil palm harvested region has grown 
Table 2 Income generated by agriculture-based industry

\begin{tabular}{lccc}
\hline Year & 2000 & $\begin{array}{l}2005 \\
\text { RM million }\end{array}$ & 2013 \\
\hline Coca & 250 & 83 & 138 \\
Paddy & 590 & 632 & 988 \\
Livestock's & 1520 & 2089 & 2483 \\
Rubber & 1868 & 2264 & 2554 \\
Forestry & 3055 & 3016 & 2761 \\
Fisheries & 2493 & 2839 & 3875 \\
Palm oil & 5860 & 7915 & 10,068 \\
\hline
\end{tabular}

Source: Department of statistic and economic planning (DOA 2013)

tremendously while the paddy harvested region has remained continuous. Although production was doubled over the last 30 years (Grassini et al. 2013), further progress must be made to increase the production to satisfy the national demand, without resorting to unsustainable and impractical practices and with environment safety factors as a priority (Edwards et al. 2015). Without a doubt, the paddy plantation needs to be invigorated by fresh ideas and applications. For example, an assemblage of elements including improved rice cultivars and agronomic management techniques to enhance nutrient and water availability and use efficiencies and to control weeds have the potential to increase yields and could help to close the gap between production and production needed while keeping sustainability issues in mind (Adnan et al. 2020).

\section{Adoption of green fertilizer a potential resolution}

\subsection{Green technology innovation}

As an environmentally friendly technology, GT is improved and utilized in a way that it does not converse natural resource and disturb the surroundings (Mannan et al. 2017). Moreover, it is recognized as a cleaner and pollution-free technology. Besides, GT, as a system, uses state-of-the-art techniques to produce a product that is friendly to the environment. GT talks about the scheme or equipment as well as the item for consumption, which guarantees the sustainable environment, GHG emission reduction, promotes healthy food and ecosystem (Tey 2013). New fertilizer and seed input in the food production industry are referred to as the green revolution technology (FAO 2015). In this specific research area, the GF adoption develops the lifestyle of the farming community, and it also helps farmers to engage in production level improvement.

\subsection{Green fertilizer development}

The introduction of eco-friendly agriculture product is the direct result of global concern on the deteriorating environmental conditions (Hashim et al. 2017; Roopan et al. 2013). Also, green technology policy emphasizes the application and improvements of such products, equipment, and systems used to conserve the natural environment and resources (Mannan et al. 2017). These are done to mitigate the adverse impact of human activities (Hashim et al. 2017; Roopan et al. 2013). The recurring use of obsolete fertilizer 
technology in paddy production has had generated environmental degradation and social impacts. The development of environmentally friendly fertilizer is, therefore, very much needed. GF is widely recognized to be fertilizer with a controlled-release feature, which not only increases nutrient use efficiency but also reduces environmental degradation (Adnan et al. 2020).

In the agriculture industry, green fertilizer (GF) innovation refers to new fertilizer inputs. A significant emphasis on GF emerged. Practices such as mono-cropping economically efficient practices that increase yields over the short term but damages soil quality and increase the vulnerability of crops over a long time (Tey 2013). Unsustainable long-term agricultural practices are problematic at the farm level, as they reduce soil and crop quality and endanger the health of farmers (Altieri et al. 2012). Thus, a farmer's behavior, such as non-green methods, adversely affect farm productivity over time (Altieri et al. 2012).

Despite all the past studies, the research on GF adoption is limited to addressing the intentions of paddy farmers toward the adoption decision in the Malaysian context. To make farmers understand the benefits of the adoption of GF fertilizer is a core issue (Fatah et al. 2017; Zainal 2008). According to several scholars (Adnan Hezri and Ghazali 2011; Thompson et al. 2015) mentioned that the adoption decision to use GF fertilizer among farmers is only possible with the help of proper communication channels (Fig. 1).

\subsubsection{A Benefit toward the adoption of GF}

According to the policymakers, the primary target behind GF adoption is the increment of both profitability and productivity (Tey 2013; Tura et al. 2010). While, this can only be possible with the assistance of effective communication as well as the use of more cost-effective farm efforts (Borges 2017; Tey 2013). Nevertheless, a farmer can achieve his desired goal, such as productivity increment, keep up-to-date. With the help of appropriate agricultural communication, there is a need for precise information for the farmers to decide innovation for GF (Mannan et al. 2017). The GF fertilizer investment costs will decrease over the specific duration with the increased GF availability (Jochinke et al. 2007). However, the charges have persisted comparatively higher, though, subsidies or

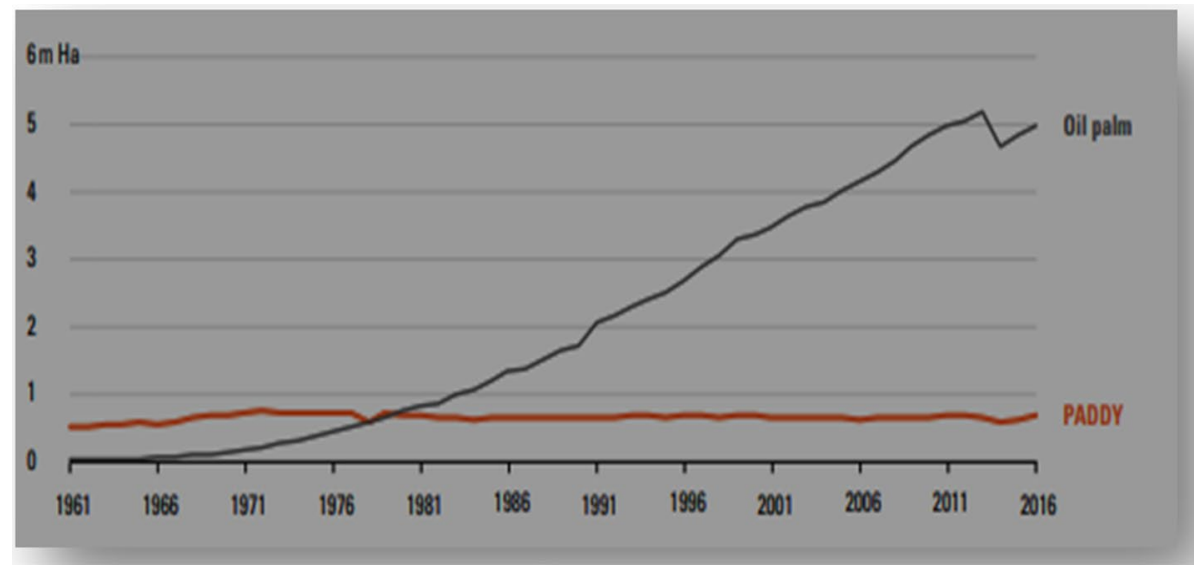

Fig. 1 Total region cultivated in Malaysia for oil palms and paddy (1961-2016) mHa Source: (Sarena Che Omar and Tumin 2019) 
incentives that have not usually been delivered to improve the GF fertilizer's affordability. Nonetheless, it is difficult to achieve the adoption decision of GF, based on the mentioned issues; scholar noticed that the cost and benefit of GF use are difficult to handle (Mannan et al. 2017). On the other hand, the known difficulty imposes to reconsider Fig. 2 of separate factors that somehow encourages farming communities to make the appropriate decision for meaningful GF adoption as it must also help to understand better for the legislator.

\section{Conceptualization and contributing factors: higher productivity in paddy}

Paddy or rice is unique among the world's major food crops by the advantage of variety as well as its adaptability to a broad range of climates, edaphic, and cultural conditions (Jamal et al. 2014). Its unique ability to grow and produce high caloric food values per unit area on all types of land, combined with its adaptation to a wide variety of climates and agricultural conditions, makes rice the most important cereal crop in Malaysia (Salehi et al. 2015). Basically, in irrigated cultivation areas in Malaysia, rice is grown through transplanted, either seeded directly into the puddled soil or seeded directly into the water. Therefore, the cultural practices in these systems often vary in a great deal. The communication to achieve a sound system in rice cultivation and production (1) land and water preparation, (2) the nursery coordination, (3) selected seed varieties, (4) sowing seeds, (5) transplanting, (6) weeding control, (7) fertilizer management, (8) integrated pest and management practices, (9) harvesting, and (10) threshing, drying and storage (Haris et al. 2013).

In principle, a higher yield can be achieved with the combination of proper rice cultivation applied environment factors, agronomic practices, and plant protection. However, these cultivation practices attained control released fertilizer (GF). Apart from that, some researchers agree that agricultural research, rural extension services, studies of rates of return, schooling, and nutrition are the key sources of productivity growth toward agriculture productivity (Avila and Evenson 2010). Agriculture productivity can also be triggered

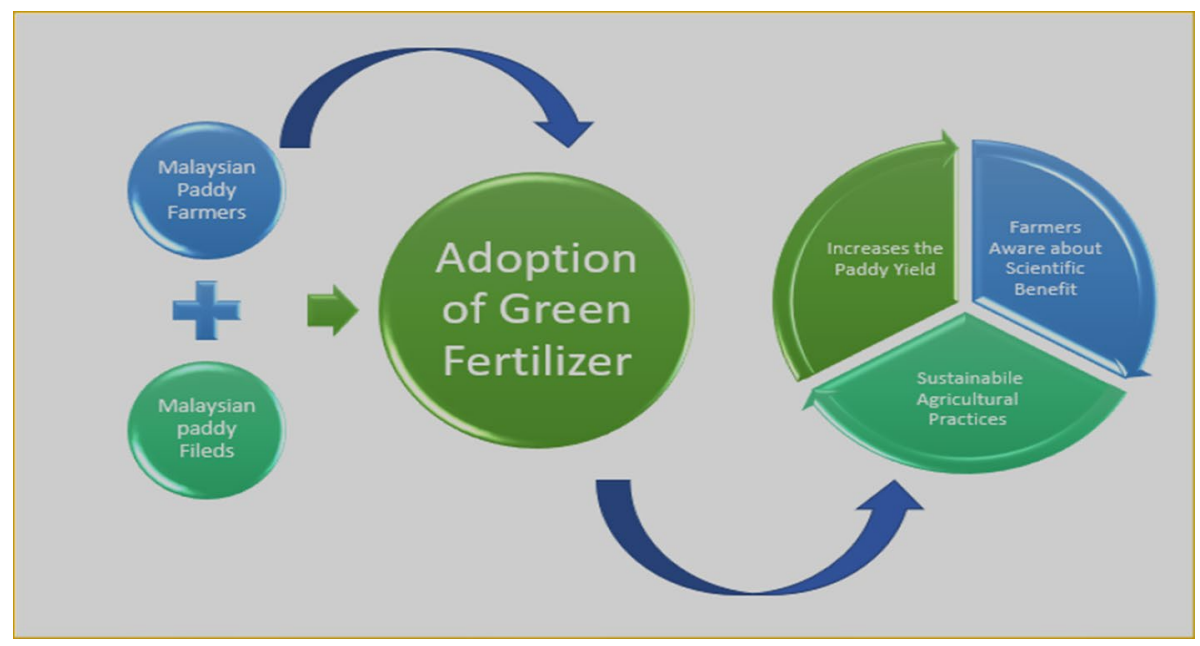

Fig. 2 Benefit toward the adoption of GF 
by inducing investment in research, extension, human capital, and infrastructure (Veisi 2012). Hence, improving the growth of agricultural productivity, not only can increase farm income but also may stimulate a linked to the non-farm rural economy, enhancing economic growth, and rapid poverty reduction (Thompson, Reimer et al. 2012). There are four forms of capital, namely economic capital (physical capital), environmental, social capital, and cultural capital or human capital. It can be referred to as owning and having control over money and other tangible assets (Pagani et al. 2017). Social capital arises from individual membership, either informal or formal networks of relationships that can foster trust, cooperation, education, empowerment, and access to resources. While human capital consists of individuals accumulated experiences, knowledge, skills, expectations, and wisdom (Borges et al. 2015), the combination of these four capitals can contribute to the productivity of individuals and communities on the whole (Naspetti et al. 2017).

Many studies had successfully included human factors as the main contribution to the adoption of innovation. For instance, (Borges et al. 2015; Morais et al. 2018; Senger et al. 2017) had found that the education and skill level, decision-making approach as well as objective orientation and physiological aspect as a representative of management level that had a positive relation toward yield production in Netherland. From the extension agriculture point of view, the decision-making process and the factors affecting them are essential in exposing them to get the best advice, make use of this advice, and consequently, positively improving the agricultural performance (Thompson, Reimer et al. 2012). Also, to increase adoption is to address the individual decision-maker actively, as it is a crucial aspect of communication (Shaffril et al. 2018). Communication also plays an essential role in the adoption of new agricultural technology in developing countries by understanding the farm-level decision-makers and creating economic incentives (Salehi et al. 2015). Hence, from the literature above, it is essential to note that decision-making about innovation is critical toward yield productivity, as well as to enhance farmers"e potential up to a certain level. However, this technology adoption decision, behavioral, and communication theories are a vast field and still require more studies in various aspects (Azarian and Dahlan 2013; Lindblom et al. 2017). Whereas, the adoption decision depends upon the range of the spectrum like socio-psychological, environment factors, innovation attributes, and communication channels (Alcon et al. 2019; Borges and Lansink 2016; Naspetti et al. 2017; Senger et al. 2017). The adoption decision of innovation only took place among farmers when several dimensions can be looked into an account. However, this research identifies numerous aspects such as agricultural communication factors, socio-psychological factors, socioeconomic, environmental factor, policy factors along with innovation attributes have a significant role in forming a farmer's behavioral intention, which, in turn, lead to their actual adoption of GF. Figure 3 illustrates the conceptual framework.

\subsection{Socio-psychological factor of innovation}

Insights and attitudes form the socio-psychological variables of the accepting components. If innovation or agricultural practice conforms to the adopting unit's opinions (perceived needs and problems) and attitudes, it is readily accepted (Borges et al. 2015). For example, farmers may not be encouraged to assimilate sustainable agriculture practices on their farms if there is no perceived that it will help to increase the paddy production level. An attitude is an inclination to respond in a manner when faced with specific stimuli (Oppenheim 1992). It is supposed that any idea, innovation, or farm practice is quickly adopted if there is a positive attitude toward the practice; else, it is not accepted. In the 


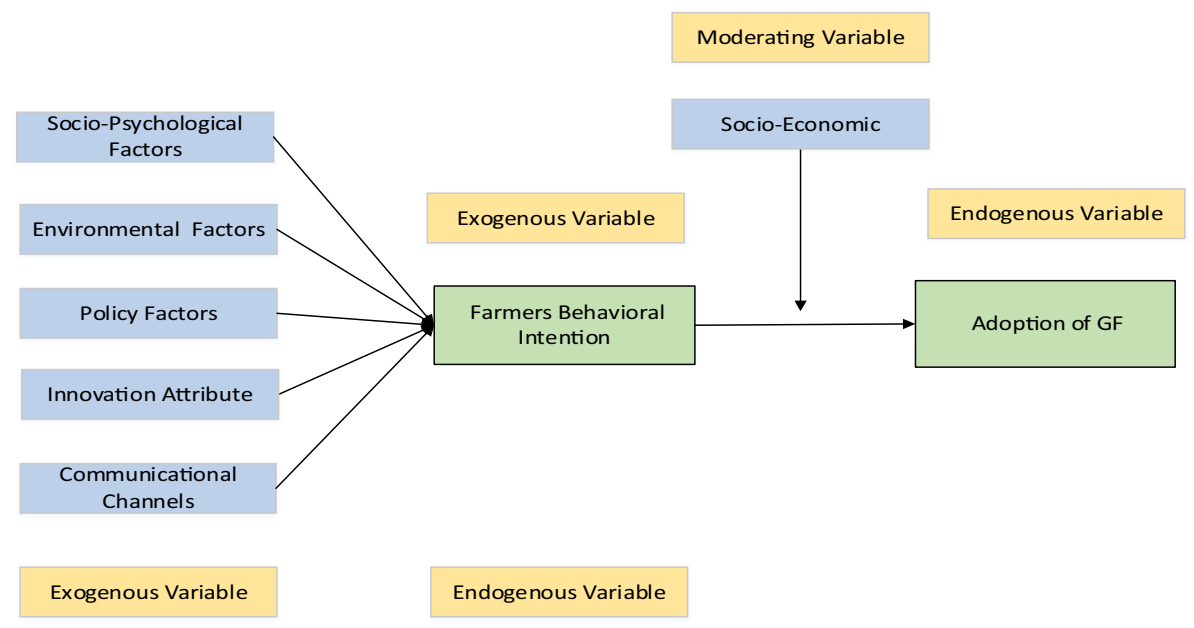

Fig. 3 Conceptual framework

past, community paddy programs were not received by the rural populations whom they were intended to help (Warner et al. 2019). Rural people see the world differently from those who design the interventions. Little is known about farmers' perceptions of trees, tree products, and related aspects compared to what is known about their perceptions of crops and practices (Lasco et al. 2019). Perception is an awareness that emerges because of a complicated weighing process a distinct goes through as their mind considers a whole host of factors and cues (Spieß and Bekkering 2020). Perception is a function of the situational fields within which an individual operates (Rogers 2010). For instance, the physical presence or absence of forests near a village can influence local farmers' perceptions of the shortage of tree products even if the farmers are not deriving any tree product from the forests. Number of studies focuses on the impact of farmers' socio-psychological variables toward the adoption of new agricultural technologies (Morais et al. 2018; Senger et al. 2017) and soil conservation technologies to enhance agricultural yield (Black and Reeve 1993; Baidu-Forson 1999; Beedell and Rehman 2000; Degrande and Duguma 2000; Spieß and Bekkering 2020). However, there is still a gap in the understanding of how these factors influence farmers to cultivate paddy in a sustainable way.

\subsection{Environment factor of innovation: Malaysia agro-environmental concern}

This study addresses enforcement styles of regulatory concern and policies, based on an examination of the municipal enforcement of agro-environmental policies in Malaysia (Hezri and Ghazali 2011). Thorough observation on the new agricultural policies adopted by the Government of Malaysia and by comparing them with the globally recognized sustainable agriculture standard, it can be pointed out that agricultural policies in the country provided substantial support to sustainable agricultural practices (Roy et al. 2016). However, the current practices, to some extent, do not meet the recognized standard, with evidence reported in the recent literature. As a response, initiatives are made, including intensive and extensive monitoring of agricultural practices and comprehensive assistance to the stakeholders by the responsible agencies that would propel Malaysia toward achieving agricultural sustainability Thompson, Reimer et al. 2012). It is that Malaysia is undergoing 
a lack of comparative edge in many food commodity productions (Alam et al. 2017). Thus, it is with high hope through the achievement of sustainable agriculture, self-sufficiency in food production can be met (Ahmad et al. 2012). Prior studies have shown that the national agriculture sector has been reinvigorated to position itself as an essential economic engine growth with the introduction of the Third National Agricultural Policy. More importantly, agriculture is a significant economic activity for rural societies in Malaysia. This study has also revealed that the Ninth Malaysian Plan period (2006-2010) was a reasonable period for the agriculture sector as it achieved a higher actual growth rate than expected. The sector also was a catalyst for economic growth and export income, mostly thanks to the increased participation of the private sector in large-scale commercial food manufacturing and agro-based industry (Shaffril et al. 2009). The same period had seen the progress of the agriculture industry intensively contributing as the third economic growth engine. However, it is a particularly practical approach which gives desire contribution toward the agriculture sector in terms of employment creation, reduction in rural poverty and reduction in the net export deficit to the national economy (Alam et al. 2017). More target specific policies and strategies are expected to be unveiled by the Ministry of Agriculture of Malaysia to further accelerate the advancement of agriculture sector into a dynamic, state of the art and globally competitive sector especially in the subsector of agricultural entrepreneur development and agro-based processing activities (Shaffril et al. 2009). The farmers are expected to increase their high productivity by adopting a green innovation that gives them social and environmental sustainability (Meijer et al. 2015).

\subsection{Policy factors of innovation: Malaysian paddy agro-environmental policies}

The rice production from the year 2000 to 2013 had an average annual growth rate of $1.47 \%$. In raw numbers, rice production grew from 2.14MT in 2000 to $2.63 \mathrm{MT}$ in 2013 (Nadir et al. 2017). However, it is due to the growing demand in total consumption as a direct result of an increase in population numbers (Roy et al. 2016). As a response, the government has introduced some policies to ensure the rice supply can meet the demand of the nation. The policy and economic plan formulation in this country has been under frequent periodic revision to confront the most critical issues as dictated by the current local and global situation (Rezaei-Moghaddam and Salehi 2010). For instance, the rice prices on the world market had endured times of instability, as was the case during the $1970 \mathrm{~s}, 1980 \mathrm{~s}$, and 2008 crisis that had a downward impact on the industry (Veisi 2012). As a result, the government had to analyze the effect of these desperate conditions on paddy farmers in terms of non-competitive rates as a consequence of the higher cost of output and the potential for a substantial decline in their income. In this research study, the researcher tries to put to attention several government policies to support the farmers and rice production industry in Malaysia.

The economic crisis in 1997 was a reset button, whereby the industrial sector faced a severe downfall while the agricultural sector provided a much-needed cushion to the downfall. The agricultural sector is seen as an effective medium to address the goal of self-sufficiency (Shaffril et al. 2010). The country's agricultural sector has undergone a series of transformations to become what it is today (Amigun et al. 2011; Raju et al. 1999). All these transformational changes have become fruitful, as its contribution to GDP improved from RM17.01 billion in 1995 to 18.22 billion in 2000 (8th Malaysian Plan). This achievement received the attention of the government and was mentioned in the 9th Malaysian Plan (2005-2010), and agriculture is acknowledged as the third-largest contributor to the 
income of Malaysians. Within the Malaysian agriculture sector in Malaysia, several commodities are extensively produced, including palm oil, cocoa, livestock and poultry, fisheries, and paddy rice. It is not a surprise that the government strongly emphasizes the paddy production industry as this industry is the most important source of carbohydrates and energy for the population (FAOSTAT 2015). The 8th to 11th Malaysian plans show how much the government has allocated for the agricultural industry within the country (Refer to Table 1).

The importance of the agricultural sector was elevated through high commitments from various component agencies related to the agriculture sector. During the Eighth Malaysian Plan period (2001-2005), the focus was given to enhancing the development of agricultural land, particularly concerning increased agro-community productivity. The in-situ land development approach continued to be adopted as a strategy to utilize the land resources of smallholders even better and to overcome the limitations of suitable land (Sarena Che Omar and Tumin 2019). The improvement of production and value-added products for exports inspired farmers to shift into large scale and commercial farming, and the broadening of adoption of the group farming system was an indicator of the high performance of the agriculture sector during this time (Sarena Che Omar and Tumin 2019). Throughout the duration of the plan, paddy production was increased due to the fully mechanized farming operations, and as a result, the income of farmers was further increased.

During in the Ninth Malaysia Plan period (2006-2010), the transformation of agriculture was focused on moving from traditional farming into modern and commercial agriculture, developing agriculture entrepreneurs, and familiarizing farmers and small landholders with all the new agronomic and modern farm management practices as contained in Good Agriculture Practice (GAP) (Guo et al. 2020). The consolidation of small paddy farming was continued through the group farming concept in eight integrated paddy areas, and the ten metric tons per hectare $(\mathrm{mt} / \mathrm{ha})$ project was implemented throughout the period (Sarena et al. 2019). These initiatives were proposed to energize the agriculture sector to become the so-called third engine of growth in the country. One objective was to develop greater commercialization and more high-income farmers through active participation in the decision-making process. As, of note was the critical role the vision that extension agents were to assist in facilitating and inspiring farmers to sustain the agriculture sector is surging demand for food, feed, and biofuels, and a rise in energy rates as well as increasing scarcity of water and land (Sarena et al. 2019). As a result, the government took the initiative to shift the agriculture industry to higher-value production by introducing methods such as aquaculture, floriculture, swiftlet farming, and large-scale farming. Nevertheless, the early stages of this shift were not easy, due to limitations such as a lack of arable land, financing, support services, skilled labor, and the inability to achieve economies of scale (Christina Chin 2011). Hence, the government unveiled a comprehensive strategy for years to come. However, in 2008, the global food shortage affected Malaysia. This shortage was due to several reasons such as oil price hikes, drastic climate change, upgrade the industry into large-scale, high-value production in the Tenth Malaysia Plan (2006 to 2010).

As the government mainly focused on rice production because rice is the staple food in the country (Rahim et al. 2012). Several targets were set, such as increasing the rice stockpile to 292,000 tones, sufficient to support the consumption of the whole population for 45 days. Another goal was to increase the productivity of the existing significant and nonmajor rice plantation areas, setting the local production of rice to match $70 \%$ of total rice self-sufficiency (Mannan et al. 2017). Therefore, the government made several policy initiatives for the Agricultural Industry in Malaysia, which is mentioned in Table 3. The continuing challenges in the paddy sector as farmers are not adequately following the policy 
Table 3 Policy initiative for the agricultural industry in Malaysia

Policy Initiatives

Environmental Quality Act (EQA) (1974)

The act focuses on the scope of reduction, prevention, and management of pollution. The implementation of the act is under the responsibility of the Department of Environment Malaysia (DOE)

The primary focus of regulation: Environmental impact assessment (EIA), Water pollution (e.g., municipal, industrial and agro-based wastewater pollution), emission pollution (e.g., motor vehicle and industrial emission), and hazardous and toxic waste management

Third Malaysian Plan (1976-1980)

The government recognized the need for serious attention regarding environmental issues

Environmental concerns were progressively integrated into Agro-based industry development plan major commodities are palm oil, paddy coca rubbers

Fourth Malaysian Plan (1976-1980)

Addressed environmental awareness by allowing greater information access

The government invested in large R\&D initiatives in paddy, rubber, and palm oil fertilizer-processing industries with the objectives of promoting indigenous treatment technology and improving compliance to increasingly strict standards

Environmental Quality (Sewage and Industrial Effluent) Regulation 1979 was enforced in 1981

Local authorities were put to the task of handling solid waste disposal and toxic waste management

The introduction of the ASEAN Environmental Program (ASAP) (1983-1985)

Fifth Malaysian Plan (1986-1990)

The original objective was to boost the development of the rural area to improve the socioeconomic wellbeing of the farming community

Agricultural development and the provision of a wide range of public services were introduced, such as utilities, education, healthcare, and access to major roads

The performance of the agricultural sector, specifically the paddy sector, has been going downtrend since 1970

As a result, the government reviewed the performance of the paddy sector, putting the expected performance and comparison with the other sectors of the economy into perspective. The government acknowledged the need to make a proper structure and organization to enhance the dynamic progress of the paddy sector

The intensive effort is imprinted in the formulation of the long-term and comprehensive NAP. The principal objective of the NAP is to focus on modernization and reinvigoration of the agriculture sector

The core of the NAP is to boost productivity and competitiveness in the development of new resources

Sixth Malaysian Plan (1990-1996)

The Plan was unveiled during heightened challenges present in the agricultural sector development

The focus of the plan is primarily based on ensuring substantial growth and improving the importance of agro-based industries to ensure a reliable and sufficient supply of agricultural inputs

There was also a highlight of the emphasis on achieving ecological balance to ensure the continuous contribution of agriculture for years to come

Relevant policies were put in place to encourage sustainable agriculture development and income-improvement practices for those who participate in the agriculture sector

The focus of paddy increase progress needs to be in tandem with the commercialization method that promotes effective resource utilization

Seventh Malaysian Plan (1996-2000)

A continuation of the development of the agriculture sector during the 6th Malaysian plan period as guided by the NAP

The sector faces an obstacle that grew slightly less than the revised target. During this period, several constraints were present, particularly labor shortage, lack of suitable land, and uncompetitive market price level of commodities

The authorized agencies focused on a sustainable paddy growth approach, which provided a competitive edge and higher income return

Environmental awareness was promoted through greater information access 
Table 3 (continued)

Policy Initiatives

Nine Malaysian Plan (2006-2010)

The 9th Malaysia Plan ought to be one of the most significant Malaysia Plans, as the nation was nearing the Vision 2020 Plan

The Plan (9MP) report was named, "Strengthening Agriculture and Agro-based Industry"

This period had seen the revitalization of the agriculture sector toward becoming the third engine of growth

The focus will be on the New Agriculture initiative which involved large-scale commercial paddy farming, wider-range of modern technology application, higher quality production of value-added products, increased potential of new fertilizer, growing biotechnology industry, increased integration of information and communications technology (ICT), and the involvement of entrepreneurial farmers and skilled labor

The responsibility of agricultural services was to be reorganized to improve service efficiency and delivery

Hence, the prospect of the agriculture sector in developing toward the direction of higher commercialization and higher-income jobs was potentially viable through active participation in the decision-making process

Tenth Malaysian Plan (2011-2015)

The Tenth Malaysia Plan highlighted the vitality of a sustainable environment as a piece of a broader comprehensive socioeconomic development strategy. It pointed out the issues of environmental damages, climate change, and sustainable use of natural resources

During this period, the government also shifted focus to the higher value of paddy agriculture activities

In the meantime, strategies were adopted to ensure adequate rice supply to satisfy local demand, including preserving the rice stockpile at 292,000 tons enough for the consumption of the whole population for 45 days, by agreeing on a long-term contract

A matching agreement to export palm oil was included in the agreements to import rice, while at the same time increasing the efficiency of the current granary and non-granary areas by adopting an innovation (i.e., new fertilizer or new seed variety)

On the contrary, no new areas were gazetted for paddy cultivation, and local production was maintained to achieve 70 percent of the self-sufficiency level.

Another strategy of food security highlighted in the 10th plan was to address the accessibility and availability of food, particularly in rice cultivation and consumption of the country

The 11th Malaysia Plan (from 2016 to 2020)

In the current Malaysia plan, a fundamental shift has been taken in the way Malaysia views the role of natural resources and the environment within its socioeconomic development. The new plan is set to encourage the practice of green growth, which sets a two-pronged focus; protecting both productivity benefits and biodiversity at the same time

The Plan was also a continuation of the focus on high-value agriculture, with an adaptation by introducing the green growth concept to it

The focus area is founded on sustainable consumption and production practices. The main goal is to advance from the conventional and costly 'grow first, clean-up later' practice to greener and modern practice-Green Growth-which put the importance of ensuring socioeconomic development that is pursued more sustainably, from the early planning stage along the way to the implementation and evaluation phases

To adopt green growth practices, an Agricultural sector, particularly paddy farming, needs to adapt to the new working environment, especially regarding regulatory and policy framework, skilled labor, green technology investment, and the availability of financial instruments

Source (Chee 2018; Bujang et al. 2016; Manaf et al. 2009; Shaffril et al. 2010; Plan 9,10,11)

(Mannan et al. 2017; Tey 2013). However, if farmers were developing these policies and strategies, which included attaining food security and sufficiency, particularly by increasing local rice production. In the end, the approach was to maintain an achievable food security level by increasing the availability and accessibility of rice to the population, which was sustainable over the long term. Adoption of green fertilizer is a solution for high paddy production and less human interaction in this pandemic situation of COVID 19. Government needs to implement new policy toward the adoption of GF(CRF BIOMASS and SRF) 
which give high production and human efforts. Table 3 illustrates the policy initiative for the agricultural industry in Malaysia.

\subsubsection{Policies on rice production}

The government has introduced and implemented many policies for the development of the rice industry in the country. These policies had started even before the Independence period and were continued in the post-independence era beginning in 1957 (Nadir et al. 2017). Before the Malaysian independence, there was a lack of substantial support programs more so in infrastructure development aspects and research and development (R\&D) efforts. Nevertheless, such policies failed in their attempts to boost rice production, where the percentage in output over the SSL had stagnated below 50\% (Ismail et al. 2017). The SSL for Peninsular Malaysia had increased to 54\% during the post-independence era, due to the implementation of assistance programs for farmers and industry in general. A significant landmark in the paddy rice industry was achieved with the construction of the Muda Irrigation system in the First Malaysia Plan (from 1966 to 1970). The mega government project allowed double-cropping per year, thus significantly increased rice production. Fast forward, a few other irrigation systems were built in other states. MARDI was established in 1969 to drive the R\&D efforts to support rice production activity. Since then, MARDI has had been at the forefront, producing several high-yield varieties (HYV) to boost rice production. Lastly, to smoothen the transfer of technology and paddy farmers' adoption of the technology, agriculture extension was widely promoted later commenced. The goals of the rice production policy in that era were as per below: To guarantee the national food security, to increase farm revenue and efficiency, to guarantee the supply of affordable food to consumers, to reduce the reliance on foreign exchange resulted from food import activity.

\subsection{Innovation attribute factor}

Innovation is described as any amendments influencing one or more surroundings of one or more vectors of features (technical, service, or expertise) resulting from a variety of fundamental mechanisms: development or dissimilarity, desertion, attendance, connotation, dissociation or planning (Rogers 2010). They may be voluntary programs, the merchandise of R\&D, strategy, and innovation activity or developing that is the fruit of natural learning mechanisms. Innovation attributes assistance to reduce innovation uncertainty and boosts the adoption rate (Rogers 2010). These attributes are made up of five innovation features: relative benefit, compatibility, complexity, trialability, observability (Rogers 2010). In terms of policy consequences, the significance of innovation factors is design for Malaysian paddy farmers (Mannan et al. 2017). This research examined the impact of innovation characteristics, for sustainable practices with the help of new fertilizer adopt an innovation (Nordin et al. 2014). The incidence of paddy growth and the magnitude of its implementation of green fertilizer technology are, therefore, explored for the current research.

\subsection{Communicational factors}

Conversely, development assistance policymakers, media professionals, and opinion-shapers have often looked for different ways to use communication systems to achieve social change among farmers about environmental risks (Jamal et al. 2014). The concern for the 
environment has challenged the education of the environment to move ahead toward a more socially critical role which involves challenging bias; whereas, this kind of rational decision-making process is to analyze the solutions and the potential for change which can be supported by the farmers (Rabu and Shah 2013). However, with the help of proper communication, farmers would receive an excellent education that would develop an understanding of the complexity of societal, behavioral, environmental concern, and agro-environmental policy regulation and cultural factors that influence the farmers toward the adoption of innovations (Adnan et al. 2020). The Role of Communication in Technology Adoption.

To examine market opportunities, constructive communication between technology developers and prospective adopters is, therefore, crucial (Nordin et al. 2014). Human beings use various devices such as words and language, pictures, drawings, and music to convey meaning and communicate with others. Communication involves the transfer of messages from a source to one or more receivers to change the behavior of the receiver (Fairuz et al. 2017). There are various channels of communication that are used to carry the messages from the source to the receiver, including mass media. Among others, mass media includes newspapers, magazines, film, leaflets, radio, and television (Rogers 2010).

\subsubsection{Agricultural communication}

Agricultural communication is a field of study and work that focuses on communication about agriculture-related information among agricultural stakeholders and between agricultural and non-agricultural stakeholders (Askarybozayeh et al. 2017). "Farmers generally are unaware of the new idea to increase production 'in its environmental sense. However, once they appreciate it, they appear to identify positively with its standards and importance" (Rezaei-Moghaddam and Salehi 2010).

\subsubsection{Agricultural communication in developing countries}

In the developing countries around the world, Agricultural Communication Technology has impacted different aspects of life and provided society with several advantages and related benefits (Asuming-Brempong et al. 2011). Regarding India, extension services are spreading information in various communities by employing information-communication technology to achieve development, most notably in the sectors of agriculture and education (Gunawardana, Mahajan et al. 2005). Likewise, in Ghana, the authorities used the same technique in the agriculture and education sectors, where they noticed a positive result (Obiechina 2004). Over the past several years, information and communication technologies have brought about significant changes in the development of economies; and by using these technologies, the economies of the countries are gradually increasing where various companies and groups, as well as entire nations, are gaining benefits from these technologies (Salehi et al. 2015). The use of Information and Communication Technologies has reduced the cost of transport as well as the barriers among communities and even countries. It has also increased the business and trade worldwide; likewise, the use of these technologies has had a positive influence over the living standards of millions of people around the world (Sachs 2005; Wright 2020; Soros et al. 2002; World Bank 2002).

The researchers pointed out the role of communication in easing the adoption of agricultural innovation among paddy farmers. The adoption process is most commonly accepted as the initial level of behavioral operation. Diffusion, in the meantime, is the process through which an innovation is transmitted among the members of a social 
system via specific media over time (Tey 2013). The functions of a communication medium for farmers will differ depending on the adoption phase, where a prospective adopter can adopt or reject the innovation. It is important to note that the complexity of human behavior often causes difficulties during the communication process (Adnan et al. 2020).

Moreover, Jan (2011) argue that modern agriculture is known among other things for the contribution of communication as a salient factor of change and progress. Historically, the agent-centered change, usually known as a Transfer of Technology approach, is often regarded as a top-down process beginning with researchers developing innovation, innovative agents promoting its use, and eventually farmers deciding on adopting or rejecting the innovation (Rezaei-Moghaddam and Salehi 2010). On the other hand, participatory assistance is a farmer/farm-based activity that offers better Communication Avenue for the passing of information on agricultural communication factors, rules, and regulations, including those regarding environmental concerns that may influence the behavior of farmers, agents of extension, and policymakers. However, it is an essential input in the development process of gaining the technical knowledge necessary for an innovation's implementation and adoption (Adnan et al. 2020). Through participatory assistance activity, researchers, agents of extension, and farmers can give inputs on their perceptions and, at the same time, receive new insight for the development and implementation of innovation later.

It is anticipated that active communication channels help to boost a better understanding of innovation, thereby encouraging its adoption. By using this formative evaluation as part of the participatory process, an end user's satisfaction is likely to be increased (Del Corso et al. 2015). Apart from that, policymakers and researchers can gather more informative feedback regarding an innovation's implementation, to propose new ways to promote or to improvise the innovation. According to Rezaei-Moghaddam and Salehi (2010), there exists a gap between the period an innovation is developed and a period when it is available in the market, and producers widely use this gap. Adoption and diffusion are the two essential innovation processes utilization. Multiple studies of adoption behavior focus on factors that answer the questions of 'if's and 'when does a particular individual adopt an innovation' (Borges et al. 2015). Adoption behavior may be measured both in terms of the timing and the extent of new technology utilization. It may be assessed by more than a variable. For example, it may be depicted by a distinct choice, i.e., yes or no to innovation adoption, or by a continuous variable which indicates to what level a divisible innovation adopted (Morais et al. 2017).

The adoption of agricultural innovation in developing countries to increase high-yield seed variety by a farmer is a discrete variable that is the farmer choose whether to opt for the new seed variety or not given a specific time (Borges et al. 2015). For example, a continuous variable is to what percentage of the farmer's plantation is used for the cultivation of this variety. However, there are several studies (Doss and Morris 2000; Sanginga et al. 2007; Tiruneh et al. 2001), studies in Ethiopia, Ghana, Nigeria, and Benin, respectively, have found that there is a gender-based communication disparity in terms of innovation adoption behavior. Effective communication toward environmental factors awareness allows researchers path to the direction of capacity building that helps the farmers to work toward achieving the high farm productivity when they choose to adopt agricultural innovation and technologies (Shaffril et al. 2018). Without a doubt, communication is essential, if not the most, toward the adoption of agricultural innovation in developing countries (Shaffril et al. 2009; Salehi et al. 2015). 
7.5.2.1 Agricultural communication in Malaysia In the Malaysian perspective, previous studies point out the fact that the role of communication is significant toward the adoption of agricultural innovation. Agricultural innovations whereby include some elements, for example, production process, processing fertilizers, and crops. All these contribute to the income for the country (Shaffril et al. 2010). Thus, it is a concern that the adoption rate of agricultural innovation among the farmers is meager in Malaysia (Shariff et al. 2014). The author's further comment that the role of communication skills, media, and methodologies is typically detested and fragmented. More often than enough, these are not adequately integrated into the total extension program (Shariff et al. 2014). It is widely agreed that modern ways of farming must be developed to meet the everincreasing demand for food by the population. To help with this, the use of multi-pronged media strategies integrated into extension programs will also increase their effectiveness (Yahaya 2001). Umar et al. (2016) similarly agree that the adoption of improved technologies contributes to increased productivity and higher income to farmers thus reduce the poverty rate within the paddy farming community in Malaysia. However, it could also potentially bring down the price of agricultural innovation products, thus creates greater economic efficiency and economic growth made possible by having proper agricultural communication.

Currently, the trend in agricultural communication within the developing countries is to prioritize the message and the social impact of its transmission (Shaffril et al. 2018). Furthermore, it is evident based on the research on communication and agricultural technology adoption. For example, Onasanya et al. (2006) have done extensive studies on the communication factors impacting innovation adoption at the community level in Malaysia. Agricultural communication in Malaysia generally relies on the variety and the range of interpersonal communication or mass media. Based on the statistics illustrated below, communication channels have substantial potential in the dissemination of agricultural innovation knowledge among farmers in Malaysia. The interpersonal channel here refers to two-way communication between two individuals or more.

Beyond any doubt, agricultural communication technologies have had a significant impact on the decision of farmers in Malaysia to adopt agricultural innovations (Asnafi and Hamid 2008). It is because the success of programs involved in agricultural development in countries that are still developing depends on quite a bit on what kind and how much mass media the authorities use in the mobilization of the people for development (Hassan et al. 2019). The parties involved in plan making in developing countries must realize that they can strengthen the agricultural development even more by effectively implementing mass media channels to allow for the adoption and use of new fertilizer technologies (Mannan et al. 2017). In Malaysia, most farmers have access to mass media. It means the probability is high that these farmers could receive a higher percentage of the messages that agencies send through the mass media.

Furthermore, Ramli Hassan et al. (2019) proved that regarding the preferred interpersonal remained the primary choice for the farmers when looking for information, education, entertainment, and other things. The research Hayrol Azril et al. (2009) undertook focused on farmers in Malaysia. In their work, they specifically focused on agriculturally based mass media and interpersonal communication, several websites which Malaysian farmers surfed for the information they require. They concluded that farmers need a strong motivation to look for and share crucial agricultural information. Adoption of green fertilizer is a solution for high paddy production and less human interaction in this pandemic situation of COVID 19. 
7.5.2.2 Essential role of information and knowledge in Malaysian paddy farmers A piece of enhanced knowledge and information flow from, to as well as within the agronomic sector, is an integral component in benefiting the agricultural production and connecting the improved output to remunerative marketplaces hence leading to upgraded rustic livings, enhancing both the quality and the yield, nationwide economy and food security (Jain et al. 2011). However, this might only be possible with the appropriate agricultural communication that permits knowledge and information to be disseminated among the farming community. Several kinds of literature have shown that there lies a positive relationship among the improved knowledge flow, adequate information, and development in the agricultural sector via effective communication (Hashim et al. 2017; Jain et al. 2011). For this purpose, the government of Malaysia has dedicated its efforts toward the knowledge dissemination as well as the information for the innovation adoption (Hashim et al. 2017). The diffusion of both the information and the knowledge toward the adoption of innovation is synchronized by effective communication (Damanpour et al. 2018). Therefore, it is vital to measure the accessibility of the agricultural knowledge and information among the paddy farmers of Malaysia (Rosmiza et al. 2014). With the advancements in the domain of knowledge and information diffusion among the farmers give a chance for them to utilize and harness knowledge and information to increase the overall productivity. Because there exist differences in the convenience and value among paddy farmers in Malaysia for the innovation transfers, it is also essential to explore the elements that can facilitate the proper application of recent innovation into exercise (Hashim et al. 2017). As a result, there is a dire need for the assessment of the needed information, the innovation role and the use and access of information and knowledge among the farmers are necessary (Bowman and Zilberman 2013; Jaim and Akter 2012). Nevertheless, the innovation adoption among the paddy farmers faces barrier as both the adoption as well as the rejection are mainly established on the behavior of farmers (Damanpour et al. 2018). However, the Rogers (1983) stated in his diffusion of innovation (DOI) models that first knowledge of an innovation forms attitude toward the adoption decision whichever to adopt the innovation or reject; after that, they approve their decision.

\subsection{Socioeconomic aspect of green fertilizer technology}

The researcher highlighted the decision-making process on agriculture in the adoption of innovation among farmers in Malaysia. Whereas, Tey (2013) observed that there are various constraints on technology and innovation decision-making among Malaysian farmers. In this research study, an attempt was made to identify the considerable constraints on the adoption decision among Malaysian farmers. These constraints are identified as: the extent to which the farmers find the new technology complex and challenging to comprehend, how readily observable the outcomes of adoption decisions are, its financial cost, the farmer's beliefs and opinions toward the technology, the farmer's level of motivation, the farmer's perception of the relevance of the new technology, and the farmer's attitudes toward risk and change (Tey 2013). Therefore, understanding this phenomenon is essential to maximize the agriculture technology adoption decision among farmers (Tey 2013). Addressing these issues of the technology adoption decision is the primary concern among agricultural economists and policymakers in Malaysia (Jaim and Akter 2012). Thus, most of the researchers have collectively suggested that the adoption decision depends on the full range of the spectrum like socioeconomic, agro-ecological, institutional, informational, and psychological as well as a cultural factor (Baumgart-Getz et al. 2012; Prokopy et al. 
2008). All these spectra of research paradigms have been led by a distinct line of studies, such as sociology, psychology, agriculture extension, economic, and marketing perspective (Pannell et al. 2006; Tey 2013). Therefore, most of the models on the adoption of innovation have inclined toward deciding between adoption (Edwards et al. 2015; Tey 2013). According to the previous studies, authors Edwards et al. (2015) and McGuire et al. (2013) proposed that there is a need for prescribed assimilation of the sociological, economic, and psychological variables in the appropriate models.

Despite all the past studies, the research on GF adoption is too limited to address the paddy farmers' intention toward the adoption decision in the Malaysian perspective. To make farmers understand the benefit of the adoption of GF fertilizer is the core issue. According to some authors (Hezri and Ghazali 2011, Reimer et al. 2012), the adoption decision of GF fertilizer is only possible when their economic and non-economic goal are satisfied. However, most of the researchers stated that the farmer's decision and behavior had been deliberated on by dual-core distinct methods like economic and non-economic, separately. For instance, we can take the purely economic literature of Austin et al. (1998), where he discussed that farmers' adoption decisions are based on normative theory. This theory assumes that the decision can be demonstrated only in a way that farmers maximize profit. Nevertheless, this literature cannot explain the complete complexity of the adoption decision among the farmers (Austin et al. 1998). The model does not produce the maximum profit and fails to recognize the farmer's behavior (Baumgart-Getz et al. 2012; Willock et al. 1999). Understanding the farmers' behavior regarding the adoption of GF requires multidisciplinary considerations. In order to overcome the issue, this research posits a better understanding through two different approaches in the field of agricultural economics about the farmer's decision and behavior.

\subsection{Adoption decision of green fertilizer technology}

There indicates regarding the adoption decision of GF is that it can facilitate the farmers to do yield increment. However, it is superior both in a technical and economic sense to flourish technologically (Lai et al. 2017; Tey 2013). The GF is very much relying on achieving a balance between financial profitability and a sustainable environment (Borges et al. 2015). So, GF for the high-value production of the commodity involved appropriate technologies for the production of the primary crop that are very promising income sources for poor farming communities (Munshi 2004). Some of the excerpts from paper demonstrations contain the following: practices of GF escalate the orchid competitiveness of some countries in Asia like Taiwan and Thailand in the worldwide market (Munshi 2004). Whereas, most of the mentioned practices comprise of bulk production with the help of micropropagation, red floral gene screening connected with RAPD markers, genetic revolution, and improvement of their grading system for orchids established on universal market demand or inclination (Borges et al. 2015).

The adoption of GF must fulfill the triangle reimbursements of consumer, producer, and service as a financially positive solution. Various studies have shown that GF adoption directly affected by several factors like the size of the farm, family size, age, education credit, availability, and information access. Dissimilar institutions and people both from inside and outside Malaysia have done numerous empirical studies in the area of the technologies associated with the adoption of agricultural innovations (Ghadiyali Tejaskumar and Kayasth Manish 2012; Kasem and Thapa 2012). However, insufficient studies have been completed so far, such as empirical analysis of the GF impact, primarily profitability, 
as well as risk attitude on the adoption decision mainly farming of paddy (Ghadiyali Tejaskumar and Kayasth Manish 2012). However, we motivated this research that clearly explains the adoption. For ease of clarity, the variables so far identified as having a connection with approval are classified as socioeconomic and psychological factors, personal household variables, institutional and informational factors, as well as the economic factors (Kasem and Thapa 2012). In the next section of our literature review, we are going to review various theories based on technology adoption, models, and we will also highlight the understanding of the mentioned theories regarding technology adoption.

It is referring to the conceptual practical framework as depicted in Fig. 2, the box labeled as the different aspect of sustainable agriculture (Tey et al. 2017). The implication of sustainable agriculture is practices that evolve indeterminately to greater personal effectiveness, higher efficacy of alternative, and steadiness with the atmosphere that is favorable for the individual. Agricultural sustainability in the dynamic nature of its fundamental components: environmental (three-dimensional and progressive relatives, assortment, steadiness, and flexibility; monetary (reserve circulation and distribution); and communal (impartiality, admittance, stewardship, and organizations)." The SAP is made up of numerous interrelating mechanisms with numerous areas. Here is the line of this research study researcher illustrated that agriculture sustainability we can get by the application of green fertilizer, which can improve the soil quality and increase the production level up to $4-11 \%$ (Yusof et al. 2019).

According to the policymakers, the primary target behind GF adoption is the increment of both profitability and productivity (Tey 2013; Tura et al. 2010). While, this can only be possible with the assistance of effective communication as well as the use of more costeffective farm efforts (Borges et al. 2015; Tey 2013). Nevertheless, a farmer can achieve his desired goal, such as productivity increment, keep up-to-date. With the help of appropriate agricultural communication, there is a need for precise information for the farmers to decide innovation for GF (Mannan et al. 2017). The GF fertilizer investment costs will decrease over the specific duration with the increased GF availability (Jochinke et al. 2007). However, the charges have persisted comparatively higher, though, subsidies or incentives that have not usually been delivered to improve the GF fertilizer's affordability.

Nonetheless, it is difficult to achieve the adoption decision of GF, based on the mentioned issues; scholar noticed that the cost and benefit of GF use are difficult to handle (Mannan et al. 2017). On the other hand, the known difficulty imposes to reconsider the figure of separate factors that somehow encourages farming communities to make the appropriate decision for meaningful GF adoption as it must also help to understand better for the legislator. The conceptual model for this study is presented in Fig. 2. Figure 4 illustrated the sustainable agricultural practices through GF.

\section{Complete summary of discussion and conclusion}

This analysis research aims to scrutinize significant factors affecting the decision of paddy farmers in the sense of GF adoption. Many aspects rely on farmers adoption, such as policy considerations, socioeconomic component of the climate, attribute of creativity, socio-psychological, means of communication, and other context factors. However, factors related to social as well as psychological belong to the core decision of adoption (Rahim et al. 2012). While, in this present review study, the authors are dealing with the domain encompassing TPB, TAM, DOI, and communication channels to study adoption decision of GF among 


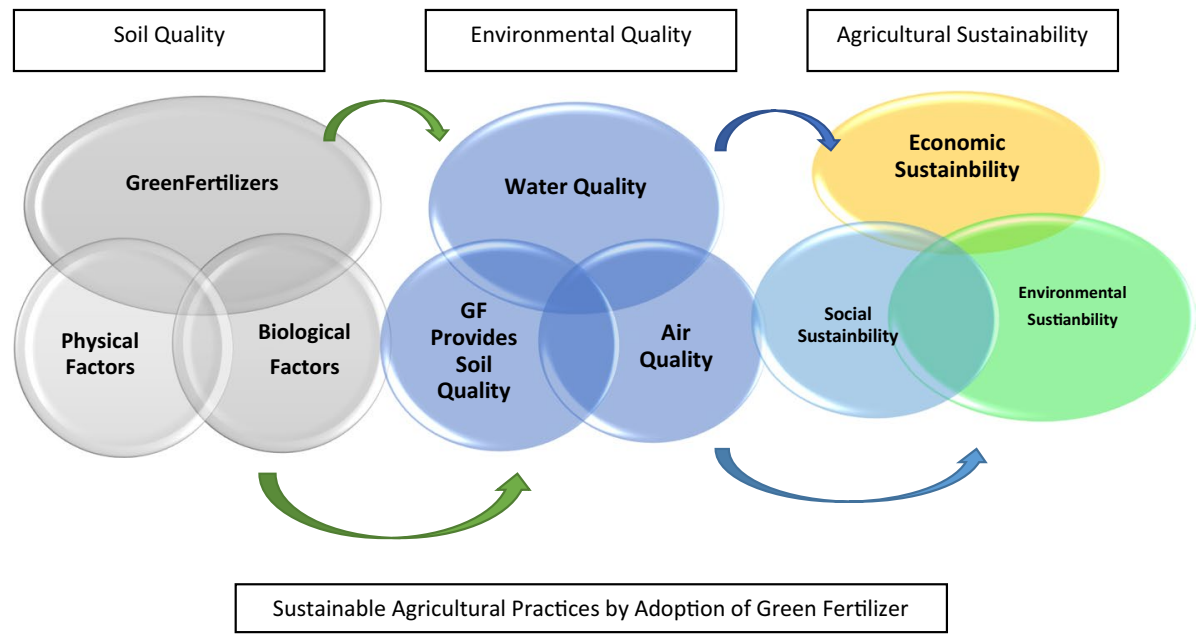

Fig. 4 Sustainable agricultural practices by Adoption of Green fertilizer

Malaysian paddy farmers. Above all, the lease of cultivable land was recommended as a vital factor in the farmers' GF adoption decision.

Nevertheless, socio-psychological benefactions are the key features that upkeep or limit the social behavior of a paddy farmer's adoption decision (Adnan et al. 2020). Therefore, it comprises of sponsorships and enticements as a primary obstacle toward the GF adoption. Furthermore, communication factors' central area is the knowledge distribution by which the information effectiveness will precisely distinguish to be a noteworthy influence toward the adoption decision among farmers (Shaffril et al. 2010).

According to the view of Rahim et al. (2012), some variables like farmers' education qualification, age, experience, income, farm size, training, households' number, and fertilizers' utilization amount are variables applied to elucidate the decision of farmers as well as behavior regarding the slow GF adoption. Irrespective of farmers' knowledge, the majority of them could not comprehend the overall cost and advantage of the GF adoption for the production regarding paddy farming (Adnan et al. 2017). Scholar noticed that the farmers who have pensiveness of their upcoming generation and proper information about the farm production are straightforwardly adopting the benefits of GF (Chambers and Conway 1992). Communication channels and innovation attributes play a vital role in building the adoption intention among Malaysian paddy farmers (Mannan et al. 2017). The aged farmers are less likely to adopt green fertilizer, whereas farmers with vast experience are diffident hence are reluctant to adopt GF due to possessing cultural norms based on communal sharing (Thompson et al. 2015).

Moreover, Mannan et al. (2017) find out that a farmer still might adopt a new agricultural practice even though it might not result in a direct profit. It is possible in reality through some financial initiatives, such as capital subsidies for the maintenance and set-up of GF, reduction in tax for the GF adopters, reducing the rate of interest, and complimentary technical for GF adoption to save costs hence increase yields. These initiatives could secondarily reshape the perceived profitability of farmers and enhance real farm profitability. Finally, there lies a more significant influence if the government shows greater support to the paddy farmers toward the adoption of modern innovation in agriculture (Ahmad 
et al. 2012; Hasin et al. 2016). The GF adoption enhances the information and awareness among more farmers about sustainability and issues and challenges that are tackled by Malaysian farmers in producing rice hence guarantee food security by government organizations (Adnan et al. 2020). As agricultural industry has been disturbed by this coronavirus outbreak, it is further recommended all those paddy industry to encourage farmer to increase paddy production. Paddy industries may feature the current situation of COVID19 crisis and highlights the basic proactive measures such as social distance maintaining need a proper policy implication. Adoption of green fertilizer is a solution for high paddy production and less human interaction in this pandemic situation of COVID 19. Government needs to implement new policy toward the adoption of GF(CRF BIOMASS and SRF) which give high production and human efforts.

Acknowledgements Researcher would like to thank Universiti teknologi Petronas and Management \& Humanities Department. Furthermore, researcher would like to acknowledge LRGS and YUTP grant for their financial support.

\section{References}

Abdollahzadeh, G., Sharifzadeh, M. S., \& Damalas, C. A. (2015). Perceptions of the beneficial and harmful effects of pesticides among Iranian rice farmers influence the adoption of biological control. Crop Protection, 75, 124-131.

Abdulkarim, B., Yacob, M. R., Abdullahi, A. M., \& Radam, A. (2017). Farmers' perceptions and attitudes toward forest watershed conservation of the North Selangor Peat Swamp Forest. Journal of sustainable forestry, 36(4), 309-323.

Adnan, N., et al. (2017). The impacts and visions of the green fertilizer technologies (GFT). World Journal of Science, Technology and Sustainable Development.

Adnan, N., Nordin, S. M., \& Anwar, A. (2020). Transition pathways for Malaysian paddy farmers to sustainable agricultural practices: An integrated exhibiting tactics to adopt Green fertilizer. Land Use Policy, 90, 104255.

Adnan, N., Nordin, S. M., Bahruddin, M. A., \& Tareq, A. H. (2019). A state-of-the-art review on facilitating sustainable agriculture through green fertiliser TechnologyAdoption: assessing farmers behavior. Trends in Food Science \& Technology, 89, 439-452.

Adnan, N., Nordin, S. M., Rahman, I., \& Noor, A. (2017). Adoption of green fertilizer technology among paddy farmers: A possible solution for Malaysian food security. Land use policy, 63, 38-52.

Ahmad, A. L., Rahim, S. A., Pawanteh, L., \& Ahmad, F. (2012). The understanding of environmental citizenship among Malaysian youths: A study on perception and participation. Asian Social Science, $8(5), 85$.

Ajzen, I. (1991). Theories of Cognitive Self-RegulationThe theory of planned behavior. Organizational Behavior and Human Decision Processes, 50(2), 179-211.

Aker, J. C. (2011). Dial "A" for agriculture: A review of information and communication technologies for agricultural extension in developing countries. Agricultural Economics, 42(6), 631-647.

Alam, M., Siwar, C., Murad, W., Molla, R. I., \& Toriman, M. E. b. (2010). Socioeconomic profile of farmer in Malaysia: Study on integrated agricultural development area in North-West Selangor. Agricultural Economics and Rural Development, Institute of Agricultural Economics, 7(2), 249-265.

Alam, M., Siwar, C., Murad, M., \& Toriman, M. E. (2017). Impacts of climate change on agriculture and food security issues in Malaysia: An empirical study on farm level assessment.

Alam, M. M., Siwar, C., Talib, B. A., \& Bin Toriman, M. E. (2019). The relationships between the socioeconomic profile of farmers and paddy productivity in North-West Selangor, Malaysia.

Alam, M., Siwar, C., Wahid, A. N. M., \& Talib, B. A. (2016). Food security and low-income households in the Malaysian east coast economic region: An empirical analysis. Review of Urban \& Regional Development Studies, 28(1), 2-15.

Alcon, F., Navarro, N., de-Miguel, M. D., \& Balbo, A. L. (2019). Drip irrigation technology: Analysis of adoption and diffusion processes. In Sustainable solutions for food security (pp. 269-285). Springer. 
Ali, R. B., Alvaro, D.-M., Wailes, E. J., \& Luckstead, J. (2019). Self-sufficiency and international trade policy strategies in the Malaysian rice sector: approaches to food security using spatial partial equilibrium analysis. Asian Journal of Agriculture and Development, 16(13), 25-52.

Ali, M., Man, N., Latif, I. A., Muharam, F. M., \& Omar, S. Z. (2018). The use of information and communication technologies in agricultural risk management by the agricultural extension services in Malaysia. International Journal of Agriculture, Environment and Food Sciences, 2(1), 29-35.

Al-Samarrai, M. N., Hamzah, R., Sam, S., Noriman, N., Dahham, O. S., Idrus, S. S., \& Adam, T. (2018). Slow release material from epoxidized natural rubber and rice husk composites for agriculture applications. Paper presented at the Journal of Physics Conference Series.

Altieri, M. A., Funes-Monzote, F. R., \& Petersen, P. (2012). Agroecologically efficient agricultural systems for smallholder farmers: Contributions to food sovereignty. Agronomy for Sustainable Development, $32(1), 1$.

Amigun, B., Kaggwa, M., Musango, J., Mutanga, S., Simelane, T., \& Stafford, W. H. (2011). Africa's technology options for renewable energy production and distribution. Pretoria: Africa Institute of South Africa.

Askarybozayeh, F., Keshavarzshal, F., Mojibhaghghadam, Z., \& Shahinrokhsar, P. (2017). Rice farmers' behaviors and attitudes toward agricultural extension programs in healthy food production (case of Lahijan and Amlash Counties, northern Iran). International Journal of Agricultural Management and Development, 7(1), 37-46.

Asnafi, A., \& Hamid, A. (2008). The role of ICT indeveloping of knowledge centre of Iran information and scientific evidence.

Asuming-Brempong, S., Gyasi, K. O., Marfo, K. A., Diagne, A., Wiredu, A. N., Boakye, A. A., et al. (2011). The exposure and adoption of New Rice for Africa (NERICAs) among Ghanaian rice farmers: What is the evidence? African Journal of Agricultural Research, 6(27), 5911-5917.

Austin, R. B., Cantero-Martınez, C., Arrúe, J. L., Playán, E., \& Cano-Marcellán, P. (1998). Yield-rainfall relationships in cereal cropping systems in the Ebro river valley of Spain. European Journal of Agronomy, 8(3-4), 239-248.

Avila A. F. D., \& Evenson, R. E. (2010). Total factor productivity growth in agriculture: The role of technological capital. Handbook of Agricultural Economics, 4, 3769-3822.

Azarian, M. S., \& Dahlan, A. R. A. (2013). Effectiveness of knowledge management in achieving success in Malaysian government agencies: A literature review. Information Management and Business Review, 5(7), 324-330.

Azril, M. S., Salleh, H., \& Inon, B. (2009). Level of mass media usage (television, radio and newspaper) among Malaysian agro-based entrepreneurs. Journal of Agriculture and Biology, 8, 417-419.

Baidu-Forson, J. (1999). Factors influencing adoption of land-enhancing technology in the Sahel: Lessons from a case study in Niger. Agricultural Economics, 20(3), 231-239.

Bakar, B. B. (2009). The Malaysian agricultural industry in the new millennium: Issues and challenges.

Barik, J., Panda, D., Mohanty, S. K., \& Lenka, S. K. (2019). Leaf photosynthesis and antioxidant response in selected traditional rice landraces of Jeypore tract of Odisha, India to submergence. Physiology and Molecular Biology of Plants, 25(4), 847-863.

Bates, R. H., \& Block, S. A. (2013). Revisiting African agriculture: Institutional change and productivity growth. The Journal of Politics, 75(2), 372-384.

Baumgart-Getz, A., Prokopy, L. S., \& Floress, K. (2012). Why farmers adopt best management practice in the United States: A meta-analysis of the adoption literature. Journal of Environmental Management, 96(1), 17-25.

Beedell, J., \& Rehman, T. (2000). Using social-psychology models to understand farmers' conservation behaviour. Journal of Rural Studies, 16(1), 117-127. https://doi.org/10.1016/S0743-0167(99)00043 -1 .

Black, A. W., \& Reeve, I. (1993). Participation in landcare groups: The relative importance of attitudinal and situational factors. Journal of Environmental Management, 39(1), 51-71.

Borges, J. A. R. (2017). Identifying beliefs underlying successors' intention to take over the farm. Land Use Policy, 68, 48-58.

Borges, J. A. R., Foletto, L., \& Xavier, V. T. (2015). An interdisciplinary framework to study farmers decisions on adoption of innovation: Insights from Expected Utility Theory and Theory of Planned Behavior. African Journal of Agricultural Research, 10(29), 2814-2825.

Borges, J. A. R., \& Lansink, A. G. J. M. O. (2016). Identifying psychological factors that determine cattle farmers' intention to use improved natural grassland. Journal of Environmental Psychology, 45, 89-96.

Bowman, M., \& Zilberman, D. (2013). Economic factors affecting diversified farming systems. Ecology and Society, 18(1). 
Bujang, A., Bern, C., \& Brumm, T. (2016). Summary of energy demand and renewable energy policies in Malaysia. Renewable and Sustainable Energy Reviews, 53, 1459-1467.

Chambers, R., \& Conway, G. (1992). Sustainable rural livelihoods: Practical concepts for the 21st century. UK: Institute of Development Studies.

Chee, Y. L. (2018). The Environmental Quality Act, 1974. Journal of Malaysian and Comparative Law, 8, 171-202.

Conway, G. R., \& Barbier, E. B. (2013). After the green revolution: Sustainable agriculture for development (pp. 1006-1016). Abingdon: Routledge.

Damanpour, F., Sanchez-Henriquez, F., \& Chiu, H. H. (2018). Internal and external sources and the adoption of innovations in organizations. British Journal of Management, 29(4), 712-730.

Dardak, R. A. (2015). Transformation of agricultural sector in Malaysia through agricultural policy (p. 7). Malaysia: Malaysian Agricultural Research and Development Institute (MARDI).

Davies, E. G., \& Simonovic, S. P. (2011). Global water resources modeling with an integrated model of the social-economic-environmental system. Advances in Water Resources, 34(6), 684-700.

Davis, F. D. (1985). A technology acceptance model for empirically testing new end-user information systems: Theory and results.

Degrande, A., \& Duguma, B. (2000). Adoption potential of rotational hedgerow intercropping in the humid lowlands of Cameroon (p. 103). London: Overseas Development Institute.

Del Corso, J. P., Kephaliacos, C., \& Plumecocq, G. (2015). Legitimizing farmers' new knowledge, learning and practices through communicative action: Application of an agro-environmental policy. Ecological Economics, 117, 86-96.

Doss, C. R., \& Morris, M. L. (2000). How does gender affect the adoption of agricultural innovations? Agricultural Economics, 25(1), 27-39.

Edwards, J., Johnson, C., Santos-Medellín, C., Lurie, E., Podishetty, N. K., Bhatnagar, S., et al. (2015). Structure, variation, and assembly of the root-associated microbiomes of rice. Proceedings of the National Academy of Sciences, 112(8), E911-E920.

Fahmi, Z., Samah, B. A., \& Abdullah, H. (2013). Paddy industry and paddy farmers well-being: A success recipe for agriculture industry in Malaysia. Asian Social Science, 9(3), 177.

Fairuz, K., Idris, A., Syahrizan, S., \& Noor, A. (2017). Knowledge, attitude, awareness, communication and practice among farmers towards empowerment of natural enemies in rice field in Melaka, Malaysia. International Journal of Academic Research in Business and Social Sciences, 7(11), $1225-1235$.

FAO. (2019). Food and agricultural organization of UN. http://www.fao.org/resilience/resources/resou rces-detail/en/c/1187704/.

FAOSTAT. (2015). Agriculture organization of the United Nations, 2011. FAO, Retrieved from, http:// faostat3.fao.org/faostat-gateway/go/to/download/Q/QC/S.

Fatah, F. A., Yaakub, N., \& Ahmad, A. R. (2017). The study on the economic fertilizer requirement for paddy production on a Malaysian soil. Journal of Fundamental and Applied Sciences, 9(2S), 777-798.

Foo, L.-P., Chin, M.-Y., Tan, K.-L., \& Phuah, K.-T. (2020). The impact of COVID-19 on tourism industry in Malaysia. Current Issues in Tourism, pp. 1-5.

Franzel, S., Carsan, S., Lukuyu, B. A., Sinja, S., \& Wambugu, C. (2014). Fodder shrubs for improving livestock productivity and smallholder livelihoods in Africa

Freiner, N. L. (2019). Food sovereignty, safety and security: The role of rice in Japan and Asia. In Rice and Agricultural Policies in Japan (pp. 133-156). Palgrave Macmillan, Cham.

Gaudino, S., Goia, I., Grignani, C., Monaco, S., \& Sacco, D. (2014). Assessing agro-environmental performance of dairy farms in northwest Italy based on aggregated results from indicators. Journal of Environmental Management, 140, 120-134.

Ghadiyali Tejaskumar, R., \& Kayasth Manish, M. (2012). Contribution of green technology in sustainable development of agriculture sector. Journal of Environmental Research and Development, vol, 7(1A).

Grassini, P., Eskridge, K. M., \& Cassman, K. G. (2013). Distinguishing between yield advances and yield plateaus in historical crop production trends. Nature Communications, 4(1), 1-11.

Greiner, R., \& Gregg, D. (2011). Farmers' intrinsic motivations, barriers to the adoption of conservation practices and effectiveness of policy instruments: Empirical evidence from northern Australia. Land Use Policy, 28(1), 257-265.

Guo, X., et al. (2020). Improving photosynthetic production in rice using integrated crop management in northeast China. Crop Science, 60(1), 454-465.

Haris, M., Bahiah, N., Garrod, G., Gkartzios, M., \& Proctor, A. (2018). The decision to adopt organic practices in Malaysia: a mix-method approach. 
Haris, N. B. M., Hamzah, A., Krauss, S. E., \& Ismail, I. A. (2013). Relationship between decision-making inputs and productivity among paddy farmers"e in integrated agriculture development areas (IADAs), in Malaysia. International Journal on Advanced Science, Engineering and Information Technology, 3(1), 64-70.

Harun, R. (2017). Policies and economic development of rice production in Malaysia. In http://ap.fftc. agnet.org/files/ap_policy/393/393_1.pdf.

Hashim, M. M. A., Yusop, M. K., Othman, R., \& Wahid, S. A. (2017). Field evaluation of newly-developed controlled release fertilizer on rice production and nitrogen uptake. Sains Malaysiana, 46(6), 925-932.

Hasin, A., Smith, S., \& Stieren, P. (2016). Illinois farmers markets using EBT: Impacts on SNAP redemption and market sales. Journal of Agriculture, Food Systems, and Community Development, 5(1), 179-188.

Hassan, S., Yussof, N. A., \& Galadima, M. (2019). Farmers current agriculture practices on paddy cultivation and relationship with work performance in Iada Batang Lupar, Sarawak, Malaysia. Asian Journal of Agricultural Extension, Economics \& Sociology, pp. 1-14.

Hazra, G. (2016). Different types of eco-friendly fertilizers: An overview. Sustainability in Environment, $1(1), 54$.

Hezri, A. A., \& Ghazali, R. (2011). A fair green economy. Studies of agriculture, energy and waste initiatives in Malaysia.[nd]: Friedrich Ebert Stiftung. www.fes-globalization.org/geneva/docum ents/2\%20Hezri-Ghazali.

Hosseini, S. E., \& Wahid, M. A. (2013). Feasibility study of biogas production and utilization as a source of renewable energy in Malaysia. Renewable and Sustainable Energy Reviews, 19, 454-462.

Ingram, J. (2018). Agricultural transition: Niche and regime knowledge systems' boundary dynamics. Environmental Innovation and Societal Transitions, 26, 117-135.

Ingrao, C., Bacenetti, J., Bezama, A., Blok, V., Geldermann, J., Goglio, P., et al. (2016). Agricultural and forest biomass for food, materials and energy: Bio-economy as the cornerstone to cleaner production and more sustainable consumption patterns for accelerating the transition towards equitable, sustainable, post fossil-carbon societies. Journal of Cleaner Production, 117, 4-6.

Ismail, I. B., Sabran, R., \& Ariffin, M. Y. B. M. (2017). Study of situational theory of problem solving (STOPS) in conceptualizing farmer's response towards insufficient information delivery in Malaysia. Humanities \& Social Sciences Reviews, 5(2), 124-133.

Jaim, W. M. H., \& Akter, S. (2012). Seed, fertilizer and innovation in Bangladesh: Industry and policy issues for the future. Washington, DC: International Food Policy Research Institute.

Jain, P., Nfila, R. B., Lwoga, E. T., Stilwell, C., \& Ngulube, P. (2011). Access and use of agricultural information and knowledge in Tanzania. Library review.

Jamal, K., Kamarulzaman, N. H., Abdullah, A. M., Ismail, M. M., \& Hashim, M. (2014). Adoption of fragrant rice farming: The case of paddy farmers in the east Coast Malaysia. UMK Procedia, 1, 8-17. https://doi.org/10.1016/j.umkpro.2014.07.002.

Jan, M. (2011). Role of communication in diffusion and adoption of agricultural innovations. Gomal University Journal of Research, 27(1), 111-118.

Jara-Rojas, R., Bravo-Ureta, B., Solis, D., \& Martinez, D. (2016). Production efficiency and commercialization channels among small-scale farmers: Evidence for raspberry production in Central Chile.

Jerneck, A., \& Olsson, L. (2014). Food first! Theorising assets and actors in agroforestry: Risk evaders, opportunity seekers and 'the food imperative'in sub-Saharan Africa. International Journal of Agricultural Sustainability, 12(1), 1-22.

Jochinke, D. C., Noonon, B. J., Wachsmann, N. G., \& Norton, R. M. (2007). The adoption of precision agriculture in an Australian broadacre cropping system-Challenges and opportunities. Field Crops Research, 104(1), 68-76.

Jones, P. J., Marier, E. A., Tranter, R. B., Wu, G., Watson, E., \& Teale, C. J. (2015). Factors affecting dairy farmers' attitudes towards antimicrobial medicine usage in cattle in England and Wales. Preventive veterinary medicine, 121(1-2), 30-40.

Kasem, S., \& Thapa, G. B. (2012). Sustainable development policies and achievements in the context of the agriculture sector in Thailand. Sustainable Development, 20(2), 98-114.

Lai, F.-W., Shad, M. K., \& Wahab, H. A. (2017). Economic value analysis for a government funded research program in green fertilizer technology development. Global Business and Management Research, 9(1s), 313.

Lasco, R. D., et al. (2019). Replication Data for: Smallholder farmers' perceptions of climate change and the roles of trees and agroforestry in climate risk adaptation: evidence from Bohol, Philippines.

Lee, W. C., \& Baharuddin, A. H. (2018). Impacts of climate change on agriculture in Malaysia (pp. 179-195). Berlin: Springer. 
Lindblom, J., Lundström, C., Ljung, M., \& Jonsson, A. (2017). Promoting sustainable intensification in precision agriculture: Review of decision support systems development and strategies. Precision Agriculture, 18(3), 309-331.

Mahajan, M., Acero, A., \& Platt, J. C. (2005). Hidden conditional random fields for phone classification. In Ninth European conference on speech communication and technology.

Manaf, L. A., Samah, M. A. A., \& Zukki, N. I. M. (2009). Municipal solid waste management in Malaysia: Practices and challenges. Waste Management, 29(11), 2902-2906.

Mannan, S., Nordin, S. M., \& Rafik-Galea, S. (2017). Innovation diffusion attributes as predictors to adoption of green fertilizer technology among paddy farmers in Perak State. Global Business \& Management Research, 9.

McDonald, R., Heanue, K., Pierce, K., \& Horan, B. (2016). Factors influencing new entrant dairy farmer's decision-making process around technology adoption. The Journal of Agricultural Education and Extension, 22(2), 163-177.

McGuire, K., Puchalska, B. A., \& Salter, M. (2013). State of the union report: A road map addressing reform possibilities based upon a comparative analysis of the legal regulation of hate speech and hate crime.

Meijer, S. S., Catacutan, D., Ajayi, O. C., Sileshi, G. W., \& Nieuwenhuis, M. (2015). The role of knowledge, attitudes and perceptions in the uptake of agricultural and agroforestry innovations among smallholder farmers in sub-Saharan Africa. International Journal of Agricultural Sustainability, 13(1), 40-54.

Midingoyi, S., Kassie, K. G., Muriithi, B., Diiro, G., \& Ekesi, S. (2019). Do farmers and the environment benefit from adopting integrated pest management practices? Evidence from Kenya. Journal of Agricultural Economics, 70(2), 452-470.

Mirimo, D., \& Shamsudin, M. N. (2018). Price relations between Malaysia rice sector and selected ASEAN countries. International Journal of Community Development and Management Studies, 2, 131-144.

Mohamed, A. M., \& Damin, Z. A. (2010). Industrialization and sustainable food security: New challenges for Malaysia. In Land and disaster management strategies in Asia (pp. 67-80). Springer.

Morais, M., Binotto, E., \& Borges, J. A. R. (2017). Identifying beliefs underlying successors' intention to take over the farm. Land Use Policy, 68, 48-58.

Morais, M., Borges, J. A. R., \& Binotto, E. (2018). Using the reasoned action approach to understand Brazilian successors' intention to take over the farm. Land Use Policy, 71, 445-452.

Muazu, A., Yahya, A., Ishak, W. I. W., \& Khairunniza-Bejo, S. (2015). Energy audit for sustainable wetland paddy cultivation in Malaysia. Energy, 87, 182-191.

Munshi, K. (2004). Social learning in a heterogeneous population: Technology diffusion in the Indian Green Revolution. Journal of Development Economics, 73(1), 185-213.

Nadir, S., Xiong, H.-B., Zhu, Q., Zhang, X.-L., Xu, H.-Y., Li, J., et al. (2017). Weedy rice in sustainable rice production. A review. Agronomy for Sustainable Development, 37(5), 46.

Naher, U. A., Ahmed, M. N., Sarkar, M. I. U., Biswas, J. C., \& Panhwar, Q. A. (2019). Fertilizer management strategies for sustainable rice production. In Organic Farming (pp. 251-267). Elsevier.

Naspetti, S., Mandolesi, S., Buysse, J., Latvala, T., Nicholas, P., Padel, S., et al. (2017). Determinants of the acceptance of sustainable production strategies among dairy farmers: Development and testing of a modified technology acceptance model. Sustainability, 9(10), 1805.

Nicola, M., Alsafi, Z., Sohrabi, C., Kerwan, A., Al-Jabir, A., Iosifidis, C., et al. (2020). The socio-economic implications of the coronavirus pandemic (COVID-19): A review. International Journal of Surgery, 78, 185-193. https://doi.org/10.1016/j.ijsu.2020.04.018.

Nordin, S. M., Noor, S. M., \& Saad, M. S. b. M. (2014). Innovation diffusion of new technologies in the malaysian paddy fertilizer industry. Procedia - Social and Behavioral Sciences, 109(0), 768-778. https://doi.org/10.1016/j.sbspro.2013.12.542.

Obiechina, J. (2004). ICT and agriculture: A contest project on ICT and agriculture. AYF's Seminar on ICT and Agriculture, Accra, Ghana (pp. 21-23).

Onasanya, A. S., Adedoyin, S. F., \& Onasanya, O. A. (2006). Communication factors affecting the adoption of innovation at the grassroots level in Ogun State, Nigeria. Journal of Central European Agriculture, 7(4).

Oppenheim, A. N. (1992). Questionnaire design. Interviewing and Attitude measurement (p. 24).

Osman, Z., \& Shahiri, H. (2017). Ethnic and gender inequality in employment during the new economic policy. Institutions and Economies, 57-72.

Pagani, M., Johnson, T. G., \& Vittuari, M. (2017). Energy input in conventional and organic paddy rice production in Missouri and Italy: A comparative case study. Journal of Environmental Management, 188, 173-182. 
Pannell, D. J., Marshall, G. R., Barr, N., Curtis, A., Vanclay, F., \& Wilkinson, R. (2006). Understanding and promoting adoption of conservation practices by rural landholders. Australian Journal of Experimental Agriculture, 46(11), 1407-1424.

Poppenborg, P., \& Koellner, T. (2013). Do attitudes toward ecosystem services determine agricultural land use practices? An analysis of farmers' decision-making in a South Korean watershed. Land Use Policy, 31, 422-429.

Prokopy, L. S., Floress, K., Klotthor-Weinkauf, D., \& Baumgart-Getz, A. (2008). Determinants of agricultural best management practice adoption: Evidence from the literature. Journal of Soil and Water Conservation, 63(5), 300-311.

Rabu, M. R., \& Shah, M. D. M. (2013). Food and livelihood security of the Malaysian paddy farmers.

Rahim, M. H. A., Zukni, R. Z. J. A., Ahmad, F., \& Lyndon, N. (2012). Green advertising and environmentally responsible consumer behavior: The level of awareness and perception of Malaysian youth. Asian Social Science, 8(5), 46.

Reganold, J. P., \& Wachter, J. M. (2016). Organic agriculture in the twenty-first century. Nature Plants, 2(2), 15221.

Reimer, A. P., Thompson, A. W., \& Prokopy, L. S. (2012). The multi-dimensional nature of environmental attitudes among farmers in Indiana: Implications for conservation adoption. Agriculture and Human Values, 29(1), 29-40.

Rezaei-Moghaddam, K., \& Salehi, S. (2010). Agricultural specialists' intention toward precision agriculture technologies: Integrating innovation characteristics to technology acceptance model. African Journal of Agricultural Research, 5(11), 1191-1199.

Rogers, E. M. (1983). Diffusion of Innovation. Canada.

Rogers, E. M. (2010). Diffusion of innovations: Simon and Schuster.

Roopan, S. M., Madhumitha, G., Rahuman, A. A., Kamaraj, C., Bharathi, A., \& Surendra, T. V. (2013). Low-cost and eco-friendly phyto-synthesis of silver nanoparticles using Cocos nucifera coir extract and its larvicidal activity. Industrial Crops and Products, 43, 631-635.

Rosmiza, M., Davies, W., Aznie, R. C., Mazdi, M., Jabil, M., Toren, W. W., et al. (2014). Farmers' participation in rice straw-utilisation in the mada region of kedah, Malaysia. Mediterranean Journal of Social Sciences, 5(23), 229.

Roy, R., Chan, N. W., \& Xenarios, S. (2016). Sustainability of rice production systems: An empirical evaluation to improve policy. Environment, Development and Sustainability, 18(1), 257-278.

Rupani, P. F., Embrandiri, A., Ibrahim, M. H., Shahadat, M., Hansen, S. B., \& Mansor, N. N. A. (2017). Bioremediation of palm industry wastes using vermicomposting technology: Its environmental application as green fertilizer. 3 Biotech, 7(3), 155. https://doi.org/10.1007/s13205-017-0770-1.

Sachs, J. (2005). Teacher education and the development of professional identity: Learning to be a teacher. In Connecting policy and practice: Challenges for teaching and learning in schools and universities (pp. 5-21). Routledge, Taylor and Francis Group.

Salehi, L., Rezvanfar, A., Mohammadi, S., \& Hosseini, S. (2015). Analysis of communicative factors affecting in application of sustainable rice farming practices among paddy farmers of Mazandaran Province. International Journal of Agricultural Management and Development, 5(2), 125. https:// doi.org/10.5455/ijamd.164538.

Salim, N., Chan, W. H., Mansor, S., Bazin, N. E. N., Amaran, S., Faudzi, A. A. M., Shithil, S. M. (2020). COVID-19 epidemic in Malaysia: Impact of lock-down on infection dynamics. medRxiv.

Sanginga, P. C., Kamugisha, R. N., \& Martin, A. M. (2007). Conflicts management, social capital and adoption of agroforestry technologies: Empirical findings from the highlands of southwestern Uganda. Agroforestry Systems, 69(1), 67-76.

Sarena Che Omar, A. S., \& Tumin, S. A. (2019). The status of the paddy and rice industry in Malaysia. http://www.krinstitute.org/assets/contentMS/img/template/editor/20190409_RiceReport_Full\%20Rep ort_Final.pdf.

Schaak, H., \& Mußhoff, O. (2018). Understanding the adoption of grazing practices in German dairy farming. Agricultural Systems, 165, 230-239.

Senger, I., Borges, J. A. R., \& Machado, J. A. D. (2017). Using the theory of planned behavior to understand the intention of small farmers in diversifying their agricultural production. Journal of Rural Studies, $49,32-40$.

Serra, T., \& Lansink, A. O. (2014). Measuring the impacts of production risk on technical efficiency: A state-contingent conditional order-m approach. European Journal of Operational Research, 239(1), 237-242.

Shaffril, H. A. M., Asmuni, A., \& Ismail, A. (2010). The ninth Malaysian plan and agriculture extension officer competency: A combination for intensification of paddy industry in Malaysia. Journal of International Social Research, 3(10). 
Shaffril, H. A. M., Krauss, S. E., \& Samsuddin, S. F. (2018). A systematic review on Asian's farmers' adaptation practices towards climate change. Science of the Total Environment, 644, 683-695.

Shaffril, M., Azril, H., \& D'Silva, J. L. (2009). Problems and obstacles in using information and communication technology (ICT) among Malaysian agro-based entrepreneurs. European Journal of Scientific Research, 36(1), 93-101.

Shamshiri, R. R., Ibrahim, B., Balasundram, S. K., Taheri, S., \& Weltzien, C. (2019). Evaluating system of rice intensification using a modified transplanter: A smart farming solution toward sustainability of paddy fields in Malaysia. International Journal of Agricultural and Biological Engineering, 12(2), 54-67.

Shariff, N., Muhammad, A., \& Hamidi, Z. (2014). Identification of key actors of agricultural communitybased organization from communication perspective in Malaysia. International Letters of Social and Humanistic Sciences (ILSHS), 12, 66-72.

Siddique, M. A. M., Aktar, M., \& Bin Mohd Khatib, M. A. (2013). Proximate chemical composition and amino acid profile of two red seaweeds (Hypnea Pannosa And Hypnea Musciformis) collected from St. Martin's Island. Bangladesh. Journal of Fisheriessciences Com, 7(2), 178.

Smith, R. A., Kim, Y., Zhu, X., Doudou, D. T., Sternberg, E. D., \& Thomas, M. B. (2018). Integrating models of diffusion and behavior to predict innovation adoption, maintenance, and social diffusion. Journal of Health Communication, 23(3), 264-271.

Sohrabi, C., Alsafi, Z., O’Neill, N., Khan, M., Kerwan, A., Al-Jabir, A., Agha, R. (2020). World health organization declares global emergency: A review of the 2019 novel coronavirus (COVID-19). International Journal of Surgery.

Soros, G., Dăianu, D., \& Lupescu, S. (2002). Despre globalizare. Polirom.

Spieß, L., \& Bekkering, H. (2020). Predicting choice behavior of group members. Frontiers in Psychology, 11,508 .

Tey, Y. S. (2013). The adoption of sustainable agricultural practices: an integrative approach for Malaysian vegetable farmers (Doctoral dissertation).

Tey, Y. S., Li, E., Bruwer, J., Abdullah, A. M., Brindal, M., Radam, A., Darham, S. (2017). Factors influencing the adoption of sustainable agricultural practices in developing countries: A review. Environmental Engineering \& Management Journal (Eemj), vol. 16, no. 2.

Thestar. (2019). News. Retrieved from https:/www.thestar.com.my/news/nation/2019/01/23/malaysiain-bid-to-increase-rice-production-by-5/\#piT2rMOX16jpO2qd.99

Thompson, A. W., Reimer, A., \& Prokopy, L. S. (2015). Farmers' views of the environment: the influence of competing attitude frames on landscape conservation efforts. Agriculture and Human Values, 32(3), 385-399.

Tiruneh, A., Tesfaye, T., Mwangi, W., \& Verkuijl, H. (2001). Gender differentials in agricultural production and decision-making among smallholders in Ada, Lume, and Gimbichu Woredas of the Central Highlands of Ethiopia. Cimmyt.

Tura, M., Aredo, D., Tsegaye, T., La Rovere, R., Kassie, G., Mwangi, W., \& Mwabu, G. (2010). Adoption and continued use of improved maize seeds: Case study of Central Ethiopia.

Umar, H. S., Abdullah, A. M., Shamsudin, M. N., \& Mohamed, Z. A. (2016). Implication of fertiliser subsidy withdrawal on societal welfare, rice output and imports in Malaysia's rice sector. Pertanika Journal of Social Sciences \& Humanities, 24(2).

Veisi, H. (2012). Exploring the determinants of adoption behaviour of clean technologies in agriculture: A case of integrated pest management. Asian Journal of Technology Innovation, 20(1), 67-82.

Warner, L. A., Silvert, C. J., \& Benge, M. (2019). Using adoption and perceived characteristics of fertilizer innovations to identify extension educational needs of Florida's residential audiences. Journal of Agricultural Education, 60(3).

Wauters, E., D'Haene, K., \& Lauwers, L. (2014). Social psychology and biodiversity conservation in agriculture. EAAE 2014 congress'agri-food and rural innovations for healthier societies (August 26 to 29,2014$)$.

Wheeler, S. A., Zuo, A., Bjornlund, H., Mdemu, M. V., van Rooyen, A., \& Munguambe, P. (2017). An overview of extension use in irrigated agriculture and case studies in south-eastern Africa. International Journal of Water Resources Development, 33(5), 755-769.

Willock, J., Deary, I. J., Edwards-Jones, G., Gibson, G. J., McGregor, M. J., Sutherland, A., et al. (1999). The role of attitudes and objectives in farmer decision making: Business and environmentally-oriented behaviour in Scotland. Journal of Agricultural Economics, 50(2), 286-303.

World Bank (IBRD). (2002). Constructing knowledge societies: New challenges for tertiary education. Washington, District of Columbia: World Bank.

Wright, W. (2020). How trade openness can help to 'deliver the poor and needy'. Economic Affairs, 40(1), 100-107. 
Yahaya, M. K. (2001). Integrate multi-media strategy for development support communication: Lessons from Nigeria. Journal of Development Communication, 1(2), 53-72.

Yusof, Z. M., Misiran, M., Baharin, N. F., Yaacob, M. F., Aziz, N. A. B. A., \& Sanan, N. H. B. (2019). Projection of paddy production in Kedah Malaysia: A case study. Asian Journal of Advances in Agricultural Research, 1-6.

Zainal, A. M. (2008). The Malaysian fertilizer market. IFA Crossroads Asia-Pacific.

Zepeda, L., Reznickova, A., Russell, W. S., \& Hettenbach, D. (2014). A case study of the symbolic value of community supported agriculture membership. Journal of Food Distribution Research, 45(8562016-58152), 195-212.

Zeweld, W., Van Huylenbroeck, G., Tesfay, G., \& Speelman, S. (2017). Smallholder farmers' behavioural intentions towards sustainable agricultural practices. Journal of Environmental Management, 187, 71-81.

Publisher's Note Springer Nature remains neutral with regard to jurisdictional claims in published maps and institutional affiliations. 